INDEPENDENT CONFIRMATORY SURVEY REPORT FOR THE SECTION 4 AREA AT THE RIO ALGOM AMBROSIA LAKE FACILITY AMBROSIA LAKE, NEW MEXICO

\title{
W. C. Adams
}

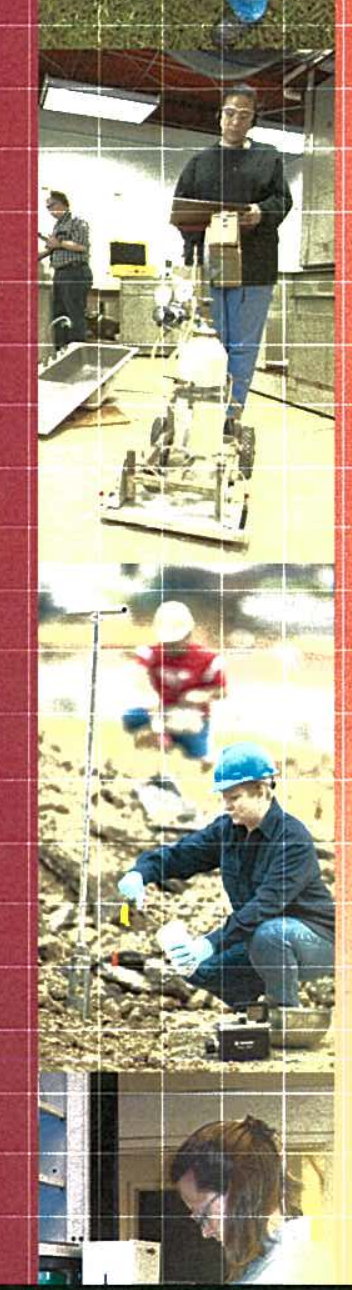

\section{Prepared for the}

U.S. Nuclear Regulatory Commission



Oak Ridge Institute for Science and Education



Approved for public release; further dissemination unlimited. 
The Oak Ridge Institute for Science and Education (ORISE) is a U.S. Department of Energy facility focusing on scientific initiatives to research health risks from occupational hazards, assess environmental cleanup, respond to radiation medical emergencies, support national security and emergency preparedness, and educate the next generation of scientists. ORISE is managed by Oak Ridge Associated Universities. Established in 1946, ORAU is a consortium of 97 colleges and universities.

\section{NOTICES}

The opinions expressed herein do not necessarily reflect the opinions of the sponsoring institutions of Oak Ridge Associated Universities.

This report was prepared as an account of work sponsored by the United States Government. Neither the United States Government nor the U.S. Department of Energy, nor any of their employees, makes any warranty, expressed or implied, or assumes any legal liability or responsibility for the accuracy, completeness, or usefulness of any information, apparatus, product, or process disclosed, or represents that its use would not infringe on privately owned rights. Reference herein to any specific commercial product, process, or service by trade name, mark, manufacturer, or otherwise, does not necessarily constitute or imply its endorsement or recommendation, or favor by the U.S. Government or any agency thereof. The views and opinions of authors expressed herein do not necessarily state or reflect those of the U.S. Government or any agency thereof. 


\title{
SECTION 4 AREA AT THE RIO ALGOM AMBROSIA LAKE FACILITY
} AMBROSIA LAKE, NEW MEXICO

\author{
Prepared by \\ W. C. Adams

 \\ Independent Environmental Assessment and Verification Program \\ Oak Ridge Institute for Science and Education \\ Oak Ridge, Tennessee 37831-0017 \\ Prepared for the \\ U.S. Nuclear Regulatory Commission
}

FINAL REPORT

FEBRUARY 2010

Prepared by the Oak Ridge Institute for Science and Education, under interagency agreement (NRC FIN No. J00610) between the U.S. Nuclear Regulatory Commission and the U.S. Department of Energy. 
CONFIRMATORY SURVEY REPORT FOR THE

SECTION 4 AREA AT THE RIO ALGOM AMBROSIA LAKE FACILITY AMBROSIA LAKE, NEW MEXICO

Prepared by: Wade C. Allan

W. C. Adams, Project Leader

Reviewed by: Evita in. Bailey for

Reviewed by: T. D. sondra

R. D. Condra, Laboratory Manager

Reviewed by: Tm Temple

A. T. Templon, Quality Manager
Date: $2 / 10 / 2010$

Date: $2 / 10 / 2010$

Date: $2 / 10 / 2010$

Date: $2 / 12 / 2010$

Rio Algom Mining

1797-SR-01-0 


\section{ACKNOWLEDGMENTS}

The author would like to acknowledge the significant contributions of the following staff members:

FIELD AND SUPPORT STAFF

T. D. Herrera

M. G. Jadick

\section{LABORATORY STAFF}

R. D. Condra

J. S. Cox

W. P. Ivey

W. F. Smith

CLERICAL STAFF

J. L. Clary

R. M. Fink

K. M. Moore

A. Ramsey

\section{ILLUSTRATORS}

A. M. Hood

J. A. Viars 


\section{TABLE OF CONTENTS}

PAGE





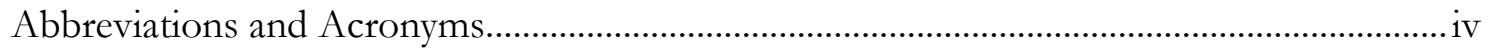

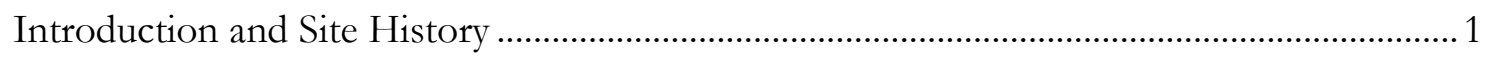

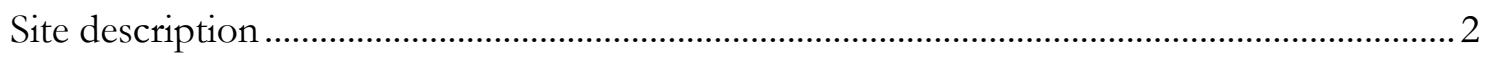

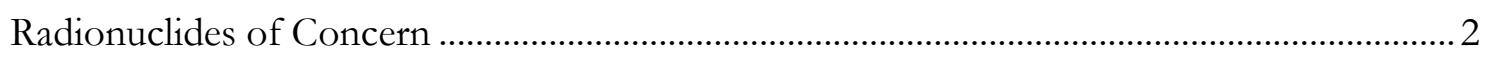



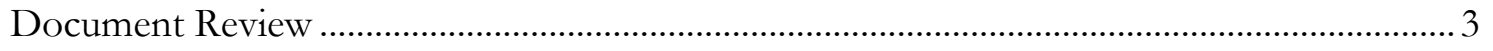

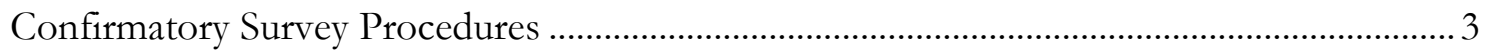





Gamma Direct Measurements................................................................................. 8

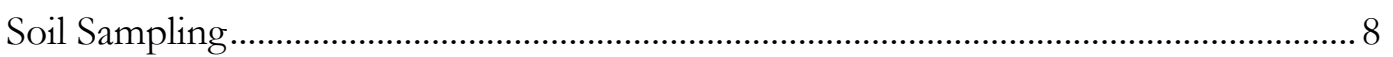

Sample Analysis and Data Interpretation ............................................................................. 9

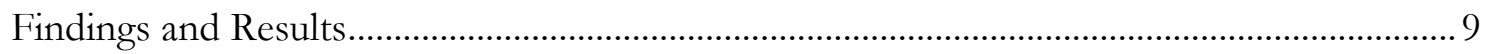

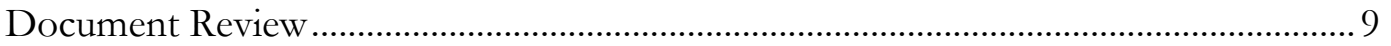

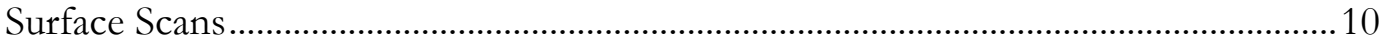

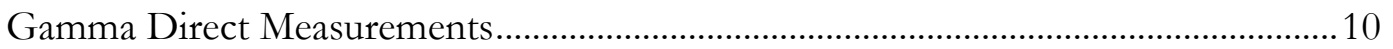



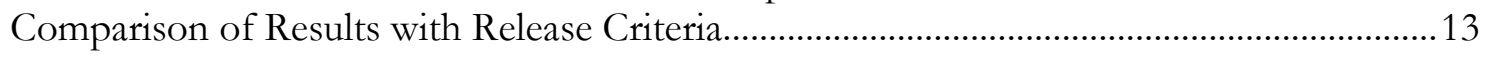

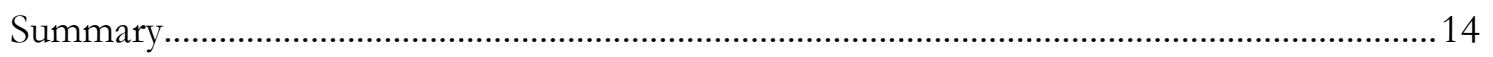



Appendices:

Appendix A: Figures

Appendix B: Tables

Appendix C: Major Instrumentation

Appendix D: Survey and Analytical Procedures

Appendix E: ORISE Statistical Survey Design for the Section 4 Ponds at the Rio Algom Mining Facility Ambrosia Lake, New Mexico 


\section{LIST OF FIGURES}

PAGE

Figure 1: Example of an RSS Measurement/Sampling Plan for Area 1...............................................6

Figure A-1: Location of Rio Algom Mining (RAM), Ambrosia Lake, New Mexico .......................... A-1

Figure A-2: Aerial Photo of Section 4 Pond Area Indicating ORISE Survey Areas ......................... A-2

Figure A-3: RAM Section 4 Ponds, Area 1 - Gamma Scans and Measurements ............................. A-3

Figure A-4: RAM Section 4 Ponds, Area 2 - Gamma Scans and Measurements .............................. A-4

Figure A-5: RAM Section 4 Ponds, Area 3 - Gamma Scans and Measurements .............................. A-5

Figure A-6: RAM Section 4 Ponds, Area 1 - Elevated Gamma Radiation And Soil Sample Locations .......................................................................................................... A-6

Figure A-7: RAM Section 4 Ponds, Area 2 - Soil Sample Locations ................................................. A-7

Figure A-8: RAM Section 4 Ponds, Area 3 - Soil Sample Locations ................................................ A-8

Figure A-9: RAM Section 4 Ponds, Area 1 - Judgmental Gamma Scan Count

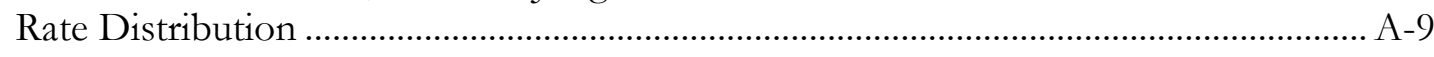

Figure A-10: RAM Section 4 Ponds, Area 2 - Judgmental Gamma Scan Count

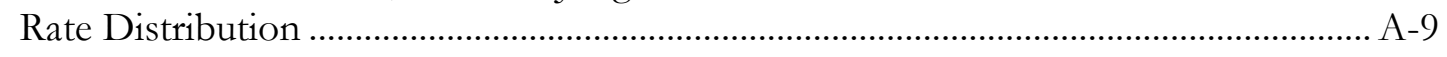

Figure A-11: RAM Section 4 Ponds, Area 3 - Judgmental Gamma Scan Count

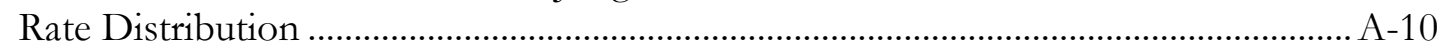

Figure E-1: Visual Sample Plan Generated Measurement Locations for

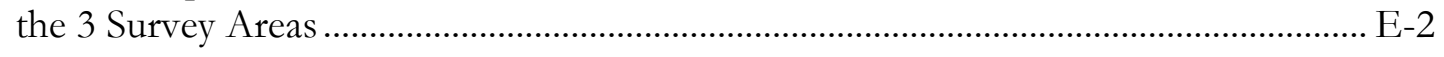




\section{LIST OF TABLES}

PAGE

Table 1: Confirmatory Survey Area Designations …...........................................................................

Table 2: ORISE Gamma Scan Density/Percentage (\%) ….............................................................

Table 3: Ranked Set Sampling Gamma Direct Measurements Summary Results................................11

Table 4: Radionuclide Concentrations in RSS Soil Samples Summary Results ....................................12

Table 5: Radionuclide Concentrations in Judgmental Soil Samples......................................................12

Table 6: Rio Algom Mining Surface Soil Cleanup Levels ...................................................................13

Table B-1: Ranked Set Sampling Gamma Measurements.......................................................................-1

Table B-2: Radionuclide Concentrations in Soil Samples Rio Algom Ambrosia Lake Facility Ambrosia Lake, New Mexico ................................................................................................... 


\section{ABBREVIATIONS AND ACRONYMS}

BKG

CFR

$\mathrm{cm}$

$\mathrm{CP}$

cpm

$\mathrm{D} \& \mathrm{D}$

DCGL

DOE

DP

EPA

FSS

FSSP

GPS

ha

IEAV

ISM

ITP

JHA

$\mathrm{kg}$

KOMEX

$\mathrm{km}$

MAPEP

MARSSIM

MDC

$\mathrm{MeV}$

$\mathrm{m}$

$\mathrm{m}^{2}$

$\mathrm{NaI}(\mathrm{Tl})$

$\mathrm{NatU}$

NIST

NRC

NRIP

ORAU

ORISE

$\mathrm{pCi} / \mathrm{g}$

RAM

Ra-226

ROC

RP

RSS

SOR

TAP

TER

Th-230 background

Code of Federal Regulations

centimeter

closure plan

counts per minute

decontamination and decommissioning

derived concentration guideline level

U.S. Department of Energy

decommissioning plan

U.S. Environmental Protection Agency

final status survey

final status survey plan

global positioning system

hectare

Independent Environmental Assessment and Verification

Program

integrated safety management

Intercomparison Testing Program

job hazard analyses

kilogram

Komex Environmental and HG Engineering Ltd.

kilometer

Mixed Analyte Performance Evaluation Program

Multi-Agency Radiation Survey and Site Investigation Manual minimum detectable concentration

million electron volts

meters

square meter

sodium iodide (thallium-activated)

natural uranium

National Institute of Standards and Technology

U.S. Nuclear Regulatory Commission

NIST Radiochemistry Intercomparison Program

Oak Ridge Associated Universities

Oak Ridge Institute for Science and Education

picocuries per gram

Rio Algom Mining

radium-226

radionuclides of concern

relative precision

ranked set sampling

sum-of-ratios

total absorption peak

technical evaluation report

thorium-230 
ABBREVIATIONS AND ACRONYMS (CONTINUED)

UMTRCA VSP
Uranium Mill Tailings Radiation Control Act

Visual Sample Plan 


\section{CONFIRMATORY SURVEY REPORT FOR THE SECTION 4 AREA AT THE RIO ALGOM AMBROSIA LAKE FACILITY AMBROSIA LAKE, NEW MEXICO}

\section{INTRODUCTION AND SITE HISTORY}

The Rio Algom Mining (RAM) Limited Liability Corporation Ambrosia Lake site began processing uranium-bearing ore in 1958. Operating under U. S. Nuclear Regulatory Commission (NRC) Source Material License SUA-1473, the site processed approximately 33 million tons of ore through 1985 and continued to be an active uranium production facility through December 2002. Reclamation of the tailings began in 1989 and included the excavation and disposal of unlined evaporation pond residues, contaminated soil cleanup, construction of surface water erosion protection features and the demolition of the mill buildings (NRC 2006).

Construction of the Section 4 evaporation ponds commenced in 1976 and was completed in 1979. The ponds were used to evaporate liquid wastes generated from RAM's processing mill. The ponds remained in active service until April 2004; reclamation activities included the pond sediments being relocated to the main tailings disposal area (KOMEX 2006). Other reclamation activities included the excavation and disposal of unlined evaporation pond residues, contaminated soil clean-up, completion of the majority of the required reclamations for Impoundments 1 and 2, construction of a rock apron on Impoundment 2 and demolition of the conventional milling structures and most support facilities. Additional activities at the site included the construction of erosion protection features adjacent to the tailings disposal facility.

On January 19, 2005, the RAM submitted a Soil Decommissioning Plan for its Ambrosia Lake uranium mill tailings facility, specifically the evaporation ponds, to the NRC. The NRC requested, in several comment letters, that RAM provide additional information and a revised plan (NRC 2006). RAM issued a revised decommissioning plan (DP) that addresses the methods and procedures implemented to ensure soil remediation meets the requirements of the Uranium Mill Tailings Radiation Control Act (UMTRCA) and NRC regulations contained within the Code of Federal Regulations (CFR)

Title 10, Part 40, Appendix A. The DP presents the geographical site, pertinent background information and the design for surface reclamation of the Section 4 evaporation ponds sediment material which is considered byproduct material as defined by the Atomic Energy Act of 1954. 
As per the CFR requirements, the DP addresses the disposal of the uranium mill tailings in a manner as to protect human health and the environment (NRC 2006).

At the request of the NRC's Headquarters and Region IV Offices, the Oak Ridge Institute for Science and Education (ORISE) performed confirmatory radiological surveys of the Section 4 Area evaporation ponds at the RAM Ambrosia Lake facility in Ambrosia Lake, New Mexico.

\section{SITE DESCRIPTION}

RAM's Ambrosia Lake site is located in the Ambrosia Lake mining district in the southeastern part of McKinley County, New Mexico, approximately 25 miles north of Grants, New Mexico (Figure A-1). The Grants Uranium Belt, specifically the Ambrosia Lake mining district, contained numerous mining companies which operated two uranium ore processing mills and over 20 underground uranium mines within the Ambrosia Lake valley. Forty years of mining and milling activities throughout the valley has led to extensive surface disturbance within the area. The Section 4 evaporation ponds, consisting of Ponds 11 through 21, are located entirely within Section 4 along the southeastern portion of the site (Figure A-2). Overall, the Section 4 Ponds cover approximately 300 acres.

\section{RADIONUCLIDES OF CONCERN}

The radionuclides of concern (ROCs) for the RAM Ambrosia Lake Facility are those associated with the uranium decay series and are natural uranium (NatU), thorium-230 (Th-230), and radium-226 (Ra-226). These radionuclides, in addition to being present as natural background constituents, may also be present in the surrounding area as a result of extensive uranium mining activities that occurred adjacent to the RAM mill facility.

\section{OBJECTIVES}

The objectives of the confirmatory survey were to verify that remedial actions were effective in meeting established release criteria and that documentation accurately and adequately described the final radiological conditions of the RAM Ambrosia Lake, Section 4 Areas. 


\section{DOCUMENT REVIEW}

ORISE personnel reviewed the DP, closure plan (CP), the final status survey plan (FSSP) and the technical evaluation report (TER) for the soil decommissioning in preparation for confirmatory survey activities for the Section 4 Areas (KOMEX 2006, MAXIM 2004, NRC 2006). Information was evaluated to assure that final status survey (FSS) procedures were appropriate for the ROCs and that residual radionuclide concentration levels satisfied the established radiological release criteria.

\section{CONFIRMATORY SURVEY PROCEDURES}

ORISE personnel visited the Ambrosia Lake Facility from September 21 through 24, 2009 to perform visual inspections and independent measurements and sampling. The confirmatory survey activities were conducted in accordance with a site-specific confirmatory survey plan, the ORISE Survey Procedures Manual and the Oak Ridge Associated Universities (ORAU) Quality Program Manual (ORISE 2009a and 2008 and ORAU 2009).

RAM has delineated the areas into affected, unaffected areas, and mining-affected areas. Areas not expected to contain radioactive contamination attributable to licensed activities and that have not been impacted by mining activities were classified as unaffected areas (natural background). Unaffected areas were generally located upwind and possess natural background concentrations of ROCs and gamma radiation levels. Mining-affected areas were those areas near the site unaffected by milling-related activities but where soils have been affected by mining-related activities (non-11e.(2) material). The impacted (affected) site area where ORISE performed confirmatory surveys was within Section 4 and included eleven evaporation ponds [Ponds 11 through 21 (Figure A-2)].

For the confirmatory surveys, ORISE divided the Section 4 Ponds into three survey areas. In each of the areas, ORISE performed a ranked set sampling (RSS) approach for randomly selecting one hundred square meters $\left(100 \mathrm{~m}^{2}\right)$ areas for confirmatory investigations - the fundamental compliance unit—and for determining confirmatory soil sample locations (EPA 2002). ORISE performed gamma surface scans and soil sampling in each randomly selected $100 \mathrm{~m}^{2}$ area grid block. Due to the size of the three survey areas, the logistics for surveying the uneven terrain, and the time constraints for the confirmatory survey activities, with concurrence from the NRC lead inspector, 
ORISE reduced the originally planned confirmatory survey activities by 40\% (54 grid blocks instead of 90 and 18 soil samples instead of 30). This deviation was documented in the site logbook.

There were three area sample planning groups as follows (Table 1): Area 1 consisted of Section 4 Ponds 11 through 14, Area 2 consisted of Section 4 Ponds 15 through 17 and Pond 21, and Area 3 consisted of Section 4 Ponds 18 through 20. The decision to pool the confirmatory survey data for the survey units was based on the site logistics and grouping of contiguous areas.

\begin{tabular}{|c|c|c|}
\hline \multicolumn{3}{|c|}{ TABLE 1: } \\
CONFIRMATORY SURVEY AREA DESIGNATIONS \\
\hline Survey Area & Section 4 Ponds & Size (acres) \\
\hline Area 1 & 11 through 14 & 101.6 \\
\hline Area 2 & 15 through 17, 21 & 100.9 \\
\hline Area 3 & 18 through 20 & 96.4 \\
\hline
\end{tabular}

An RSS approach was used to design the confirmatory soil sampling plan (EPA 2002). RSS provided a methodology to estimate the mean concentration of a population without requiring the assumption of a normal distribution. The process combines random sampling with the use of professional judgment to select sampling locations. The professional judgment relied upon the ability to assess the relative magnitude of gamma radiation levels between randomly selected locations. In this case, the gamma count rate data collected at randomly selected locations provided the measurable field screening method that correlates with the relative concentrations of the gamma-emitting ROCs. The count rate data obtained were then used to select a specific sampling location.

The following example explains the process. A more detailed description is provided in Appendix E.

- The Visual Sampling Plan v.5.4.1, or higher, RSS module was used to determine the necessary number of soil samples to estimate the mean. The number of measurements was based on the expected standard deviation and desired confidence level of the estimated mean.

- For this example, assume that the systematic planning process resulted in $n=18$ soil samples to estimate the mean. Since the Section 4 Ponds were divided into three areas of 
approximately equal size, each area required six soil samples. Therefore, $n_{a}=6$ soil samples for each area.

- The next step was to use a replication process on a larger random population from which the locations for the 18 soil samples will be selected.

- The replication process was referred to as a cycle, designated as $r$.

- Each cycle $(r)$ consists of multiple sets; sets were designated as $m$.

- Each set $(m)$ is comprised of a set size, or field assessment locations. The data from each set were ultimately the values that were ranked, for this example the ranked values were direct gamma counts. The set size should consist of two to five field assessment locations. For this project, a set size consisted of three locations. The gamma count data collected from the three locations associated with each set were ranked as being either low, medium, or high gamma count locations. The three ranking categories established the set size.

- The total number of repetitive cycles $(r)$ is a function of $n_{a}(6)$ and $m(3)$-or simply defined as $n_{a}=m \times r . \quad r$ for this example would therefore be $2(r=6 / 3)$.

- The number of field assessment locations per cycle, was a function of the set size and is simply $m^{2}$. The total number of field assessment locations for each area was then defined as $m^{2} \times r$ or in this example $3^{2} \times 2=18$. For the three areas, the total number of field assessments was $18 \times 3=54$.

- The 18 locations (for each area) were then both randomly grouped into cycle/sets and distributed in the survey area. The nomenclature for identifying a specific assessment location was cycle \#-set\#-arbitrary sequence \# (1, 2, or 3). The first location in cycle 1 of set 1 was designated as 1-1-1. Mapping is color coded (based on cycle ID: in this example red or green) using geometric shapes (based on set ID: in this example $\boldsymbol{\square}, \boldsymbol{\Delta}, \bullet$ ) to visually show the population of assessment locations.

- Specific measurement locations were generated via either a pseudo- or quasi-random approach. 




Figure 1: Example of an RSS Measurement/Sampling Plan for Area 1

Six random surface ( 0 to $15 \mathrm{~cm}$ ) samples (consisting of a $100 \mathrm{~m}^{2}$ grid block four-point composite soil sample) were collected from each survey area. The specific random coordinate sampled was from a preliminary random coordinate pool of 18 locations for each survey area. Eighteen sets of three locations (54 total locations for the combined three survey areas) each were then ranked as exhibiting either the lowest, middle, or highest gamma count rate. One composite sample was then collected in a cyclic process from the $100 \mathrm{~m}^{2}$ area with either the lowest, middle, or highest gamma radiation from each of these eighteen sets. The software Visual Sample Plan (VSP) v.5.4.1 was used 
to generate the random locations. Figures A-3 through A-8 illustrate the random ranking locations and the soil sample locations.

\section{REFERENCE SYSTEM}

Global positioning system (GPS) coordinates were used for referencing measurement and sampling locations. The specific reference system used was the New Mexico State Plane Coordinate System (NAD 27 horizontal). ORISE also used the GPS system to define the center of each randomlyselected 10 meter (m) x 10 m grid blocks (100 $\mathrm{m}^{2}$ areas) for which RSS survey activities were performed.

\section{SURFACE SCANS}

\section{$\underline{\text { Randomly-Selected } 100 \mathrm{~m}^{2} \text { Areas }}$}

High density (refer to Table 2) gamma radiation surface scans were conducted over the soil surface within each of the randomly-selected $100 \mathrm{~m}^{2}$ areas - 54 such areas were selected (18 from each of the three survey areas). Surface scans were performed using sodium iodide (thallium-activated) $[\mathrm{NaI}(\mathrm{Tl})]$ scintillation detectors coupled to a ratemeters or ratemeter-scalers with audible indicators. Detectors were also coupled to GPS systems that enabled real-time gamma count rate and position data capture. Field personnel relied on the audio output to identify and mark for further investigations any locations of elevated direct gamma radiation that might suggest the presence of residual contamination.

\section{$\underline{\text { Remaining Areas }}$}

Due to time constraints and site conditions (vegetation, uneven terrain, etc.), ORISE performed very low density (refer to Table 2) gamma radiation surface scans (less than 5\%) of the remaining portions of the Section 4 surface soils (Figure A-3). Locations of elevated radiation, suggesting the

presence of residual contamination, were marked and identified for further investigation. The NRC lead inspector discovered several areas of elevated gamma radiation which led to additional remediation activities by the RAM personnel. 


\begin{tabular}{|c|c|c||}
\hline \multicolumn{3}{|c||}{ TABLE 2: } \\
\hline \multicolumn{2}{|c||}{ ORISE GAMMA SCAN DENSITY /PERCENTAGE (\%) } \\
\hline RSS Selected Affected Areas & High Density & 75 to $100 \%$ \\
\hline Other Affected Areas & Very Low Density & Up to $5 \%$ \\
\hline
\end{tabular}

\section{Gamma Direct Measurements}

Gamma direct measurements were performed at four points equidistant from the grid block corners and the center of each of the 54 randomly selected $100 \mathrm{~m}^{2}$ areas. A 30-second gamma count, at $0.5 \mathrm{~m}$ height, was performed at each direct measurement location. The detector height for the gamma measurement was selected to ensure that the detector field-of-view encompassed the full $25 \mathrm{~m}^{2}$ within each quadrant of the individual grid block. The four gamma count measurements from within the respective $100 \mathrm{~m}^{2}$ area were summed for a total count for that grid block. The grid block total gamma counts collected at each of the 54 assessment locations and the data within a given cycle-set were then ranked as exhibiting either the lowest, medium, or highest gamma count.

\section{SOIL SAMPLING}

\section{$\underline{\text { Randomly-Selected } 100 \mathrm{~m}^{2} \text { Areas }}$}

Soil samples were collected in accordance with the following process within the 2 RSS cycles of each area: Set 1, lowest gamma radiation location; Set 2 medium location; Set 3 highest location. Table B-1 provides the RSS method showing field assessment data and the location selected for soil sampling.

Based on the RSS gamma direct measurement results, six grid blocks (100 $\mathrm{m}^{2}$ areas) were sampled for radionuclide concentrations in soil. From these six locations, four surface soil samples ( 0 to $15 \mathrm{~cm}$ ) were collected from four points midway between the center and grid block corners. These four samples were field composited into one soil sample from that area grid block.

\section{Judgmentally-Selected Locations}

Judgmental surface soil samples were collected from three locations based on NRC and ORISE gamma scan results. Specifically, it was determined while on site, that at several locations where 
there was white seepage from underneath the soil surface, that the seepage was sometimes indicative of elevated gamma radiation levels and soil contamination boundaries.

\section{Background Soil Samples}

ORISE did not collect background soil samples. For consistency with the licensee, background soil concentrations were not subtracted from soil samples collected in the impacted areas (KOMEX 2006).

\section{SAMPLE ANALYSIS AND DATA INTERPRETATION}

Samples and data were returned to the ORISE laboratory in Oak Ridge, Tennessee for analysis and interpretation. Sample analyses were performed in accordance with the ORISE Laboratory Procedures Manual (ORISE 2009b). Gamma measurement results were reported in units of counts per minute (cpm). Soil samples were analyzed by gamma spectroscopy for Th-230, Ra-226 and NatU. The spectra were also reviewed for other identifiable photopeaks that would not be expected at this site and none were identified. Soil sample results were reported in units of picocuries per gram (pCi/g). The data generated were compared with the approved release criteria established for the RAM. Additional information regarding instrumentation and procedures may be found in Appendices C and D.

\section{FINDINGS AND RESULTS}

The results for each verification component are discussed below.

\section{DOCUMENT REVIEW}

Komex Environmental survey unit FSS data were used to determine the number of random confirmatory samples necessary to verify the mean concentrations. Specifically, the inputs used were the respective derived concentration guideline level (DCGLs) for the primary natural radionuclides Th-230, Ra-226 and Natural Uranium. 


\section{SURFACE SCANS}

\section{$\underline{\text { RSS Grid Block Surface Scans }}$}

Gamma radiation surface scans, within the RSS selected grid blocks, did not identify any areas of elevated gamma radiation. The RSS grid blocks [represented by their associated RSS symbols $(\mathbf{\square}, \mathbf{\Delta}$, $\bullet, \square, \Delta$, and $\bullet$ )] that received gamma scans are presented in Figures A-3 to A-5. The gamma scan ranges within each grid block are provided in Table B-1 and ranged from 2,450 to 9,430 cpm for Area 1; 3,858 to 7,397 cpm for Area 2; and, 2,609 to 7,294 cpm for Area 3.

\section{Judgmental Surface Scans}

Judgmental gamma scan walkover results are illustrated in Figures A-3 through A-5 for each area. Survey area gamma scan count rates generally ranged from 4,500 to 7,000 cpm with the variability in the ambient gamma radiation levels consistent with the localized area topography and geology. Data are provided as the gross, observed count rates. Figures A-9 through A-11 provides frequency histograms of the judgmental walkover gamma count rate data population for each of the survey areas.

Cursory gamma scans by the NRC lead inspectors for the site and ORISE personnel identified several locations of elevated gamma radiation levels on soil surfaces associated with a white seepage from beneath the soil surface. These locations were logged into the GPS units and were reported to RAM personnel for further evaluation. These judgmental locations are referenced on Figure A-6 and are represented as $(\mathrm{J} \#)$.

\section{Gamma Direct MEASUREMENTS}

\section{$\underline{\text { RSS Gamma Measurements }}$}

The summary data for the three combined survey groupings are presented in Table 3 below; the average background gamma count rate was $6,138 \mathrm{cpm}$. The data for the individual direct gamma measurements are provided in Table B-1. 


\begin{tabular}{|c|c|c|}
\hline \multirow{3}{*}{ TABLE 3: } \\
\multirow{2}{*}{ RANKED SET SAMPLING GAMMA DIRECT MEASUREMENTS } \\
SUMMARY RESULTS \\
\hline \multirow{2}{*}{ Survey Areas by Ponds } & Gamma Direct Measurement (cpm) \\
\cline { 2 - 3 } & Minimum & Maximum \\
\hline Area 1: Ponds 11 to 14 & 9,261 & 12,307 \\
\hline Area 2: Ponds 15 to 17, 21 & 8,907 & 11,187 \\
\hline Area 3: Ponds 18 to 20 & 8,041 & 10,987 \\
\hline Background (North of site) & 5,111 & 8,128 \\
\hline
\end{tabular}

\section{Judgmental Gamma Measurements}

The judgmental gamma direct measurements at the five locations (J1 through J5) as indicated on Figure A- 6 ranged from 14,000 to $29,000 \mathrm{cpm}$ on the surface and from 23,000 to $66,000 \mathrm{cpm}$ at $45 \mathrm{~cm}$ depth. Based on these measurements, the licensee initiated further remedial actions in these areas. At the end of the ORISE survey activities, ORISE performed post-remediation measurements at two locations where RAM personnel had completed remediation activities (J2 and J4) and the gamma measurements were 5,400 and 5,300 cpm, respectively.

\section{RADIONUCLIDE CONCENTRATIONS IN SOIL SAMPLES}

\section{$\underline{\text { RSS Soil Samples }}$}

The summary data for the three combined survey groupings are presented in Table 4 below. The data for the radionuclide concentrations in individual samples and the sum-of-ratios are provided in Table B-2. The gamma count rate data used for selecting the appropriate sample locations are shown in Table B-1. 


\begin{tabular}{|c|c|c|c|c|}
\hline \multicolumn{5}{|c|}{$\begin{array}{l}\text { TABLE 4: } \\
\text { E CONCENTRATIONS IN RSS SOIL SAMPLES } \\
\text { SUMMARY RESULTS }\end{array}$} \\
\hline \multirow{2}{*}{ Survey Areas by Ponds } & \multicolumn{4}{|c|}{ Radionuclide Concentrations (pCi/g) } \\
\hline & Th-230 & Ra-226 & NatU & SOR $^{\mathrm{a}}$ \\
\hline Area 1: Ponds 11 to 14 & 3.4 to 92.8 & 1.16 to 2.39 & 2.6 to 21.0 & 0.45 to 6.01 \\
\hline Mean Concentration & 25.75 & 1.50 & 7.14 & 1.92 \\
\hline Area 2: Ponds 15 to 17,21 & 0.3 to 26.3 & 0.87 to 1.17 & 1.8 to 13.2 & 0.25 to 1.88 \\
\hline Mean Concentration & 8.95 & 1.03 & 5.11 & 0.81 \\
\hline Area 3: Ponds 18 to 20 & 1.2 to 58.3 & 0.80 to 1.74 & 2.3 to 6.4 & 0.37 to 3.85 \\
\hline Mean Concentration & 13.07 & 1.16 & 4.23 & 1.05 \\
\hline Site Mean & 15.92 & 1.23 & 5.49 & 1.26 \\
\hline
\end{tabular}

aSum of ratios.

\section{Judgmental Soil Samples}

Two judgmental soil samples were collected from locations identified as having elevated gamma radiation levels during the gamma surface scans. After remediation activities by the licensee, ORISE collected two more samples from remediated areas. The radionuclide concentrations in these samples are provided in Table 5 below.

TABLE 5:

RADIONUCLIDE CONCENTRATIONS IN JUDGMENTAL SOIL SAMPLES

\begin{tabular}{|c|c|c|c|c||}
\hline \multirow{2}{*}{ Area 1 Ponds } & \multicolumn{4}{|c||}{ Radionuclide Concentrations (pCi/g) } \\
\cline { 2 - 5 } & Th-230 & Ra-226 & NatU & SOR $^{\text {a }}$ \\
\hline \hline Pre-remediation & 923 to 1,500 & 18.1 to 21.5 & 16.4 to 55.4 & 58.82 to 91.25 \\
\hline Post-Remediation & 3.2 to 12.3 & 0.78 to 1.53 & 1.9 to 3.6 & 0.35 to 1.04 \\
\hline
\end{tabular}

aSum of ratios 


\section{COMPARISON OF RESULTS WITH RELEASE CRITERIA}

The primary ROCs are natural uranium (U-234, U-235 and U-238), Th-230 and Ra-226. The applicable site-specific cleanup levels for the ROCs are provided in Table 6. To demonstrate compliance with the Table 6 criteria, each radionuclide concentration should be less than its respective cleanup level—with consideration for small areas of elevated activity—as well as application of the unity rule [sum-of-ratios (SOR)]. The unity rule requires that the sum of the concentration of each contaminant divided by the respective guideline be less than one.

\begin{tabular}{|c|c|}
\hline \multicolumn{2}{|c|}{ TABLE 6: } \\
\hline RIO ALGOM MINING SURFACE SOIL CLEANUP LEVELS \\
\hline Radionuclide & Soil Guidelines(pCi/g) $^{\mathbf{a}}$ \\
\hline \hline Natural Uranium & 38 \\
\hline Th-230 & $17^{\mathrm{b}}$ \\
\hline Ra-226 & 7 \\
\hline
\end{tabular}

${ }^{a}$ Cleanup levels from Section 8: Final Status Survey Plan within the Soil Decommissioning Plan (KOMEX 2006). These values include background. Also, the sum-of-ratios (SOR) must be less than 1. bSection 8.1.1.3 initial Th-230 cleanup level was $14 \mathrm{pCi} / \mathrm{g}$. As this level did not include background, the Th-230 cleanup level was revised to $17 \mathrm{pCi} / \mathrm{g}$ (RAM 2008).

Radionuclide concentrations in soil samples were directly compared with the Th-230, Ra-226, and $\mathrm{NatU}$ release limits of 17.0, 7.0 and $38 \mathrm{pCi} / \mathrm{g}$, respectively. ORISE also applied the unity rule SOR in the activity calculations for each composite soil samples.

Four of the 18 RSS soil sample results exceeded the individual ROC release criteria for Th-230 and six of the RSS soil sample results exceeded the SORs. Furthermore, the mean concentration results for Th-230 and SOR for Area 1 and the SOR mean concentration for Area 3 exceeded the soil cleanup criteria as provided above in Table 4. The calculated site mean concentrations of $15.92 \mathrm{pCi} / \mathrm{g}$ for Th-230, $1.23 \mathrm{pCi} / \mathrm{g}$ for Ra-226 and $5.49 \mathrm{pCi} / \mathrm{g}$ for $\mathrm{NatU}$ did not exceed the individual ROC soil cleanup levels; however, the site mean SOR of 1.26 exceeds the unity rule. ORISE did not compare to RAM FSS mean concentrations since FSS data was not provided to ORISE. 
Two judgmental soil samples (S019 and S020) collected prior to additional remediation by the licensee exceeded the individual ROC release criteria. Soil sample location S019 was remediated while ORISE was onsite and ORISE collected a post-remediation sample (S021). The results indicate that the ROC concentrations were significantly reduced with individual ROC concentrations below their individual DCGL release criteria; however, the SOR for SO21 still exceeded unity.

\section{SUMMARY}

During the period of September 21 through 24, 2009, ORISE performed independent confirmatory measurements and sampling activities on the Section 4 Ponds at the RAM Ambrosia Lake Facility in New Mexico. The confirmatory survey results indicate that further investigation and possible remediation are necessary before the release limits are satisfied. 


\section{REFERENCES}

Komex Environmental and HG Engineering Ltd (KOMEX). Soil Decommissioning Plan: Rio Algom Mining LLC, Ambrosia Lake Facility, Grants, New Mexico. Golden, Colorado; May 1, 2006.

Maxim Technologies, Inc. (MAXIM). Closure Plan: Lined Evaporation Ponds. Rio Algom Mining LLC, Ambrosia Lake, New Mexico. Hilliard, Ohio; October 2004.

Oak Ridge Associated Universities (ORAU). Quality Program Manual for the Independent Environmental Assessment and Verification Program. Oak Ridge, Tennessee; June 30, 2009.

Oak Ridge Institute for Science and Education (ORISE). Survey Procedures Manual for the Independent Environmental Assessment and Verification Program. Oak Ridge, Tennessee; May 1, 2008.

Oak Ridge Institute for Science and Education. Confirmatory Survey Plan for the Section A Area at the Rio Algom Ambrosia Lake Facility, Ambrosia Lake, New Mexico. DCN 1797-PL-01-0

(Docket No. 040-8905; NRC F1000; RFTA No. 09-011). Oak Ridge, Tennessee; September 11, 2009a.

Oak Ridge Institute for Science and Education. Laboratory Procedures Manual for the Independent Environmental Assessment and Verification Program. Oak Ridge, Tennessee; June 30, 2009b.

Rio Algom Mining LLC (RAM). Letter from T. Fletcher (RAM) to T. McLaughlin (NRC), RE: License SUA-1473, Docket No. 40-8905, Clarification Soils Decommissioning Plan. Grants, New Mexico; October 15, 2008.

U. S. Environmental Protection Agency (EPA). Guidance on Choosing a Sampling Design for Environmental Data Collection for Use in Developing a Quality Assurance Project Plan, EPA QA/G-5S. Washington, DC; December 2002.

U.S. Nuclear Regulatory Commission (NRC). Environmental Assessment for the Soil Decommissioning Plan, Rio Algom Mining LLC's Uranium Mill Facility, Ambrosia Lake, New Mexico: Final Report. License SUA-1473; Docket 40-8905. Washington, DC; May 15, 2006. 
APPENDIX A

FIGURES 


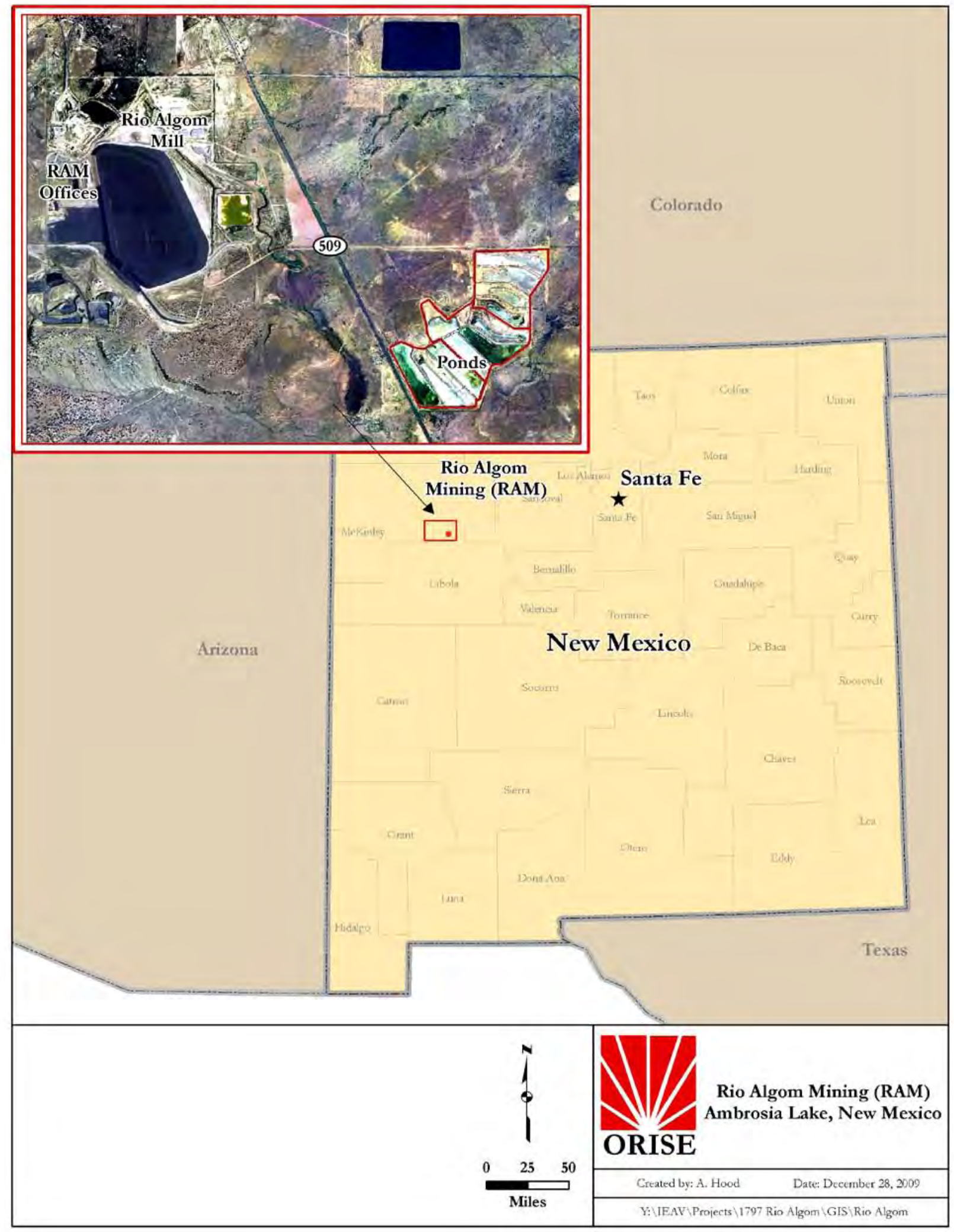

Figure A-1: Location of Rio Algom Mining (RAM), Ambrosia Lake, New Mexico 




Figure A-2: Aerial Photo of Section 4 Pond Area Indicating ORISE Survey Areas 


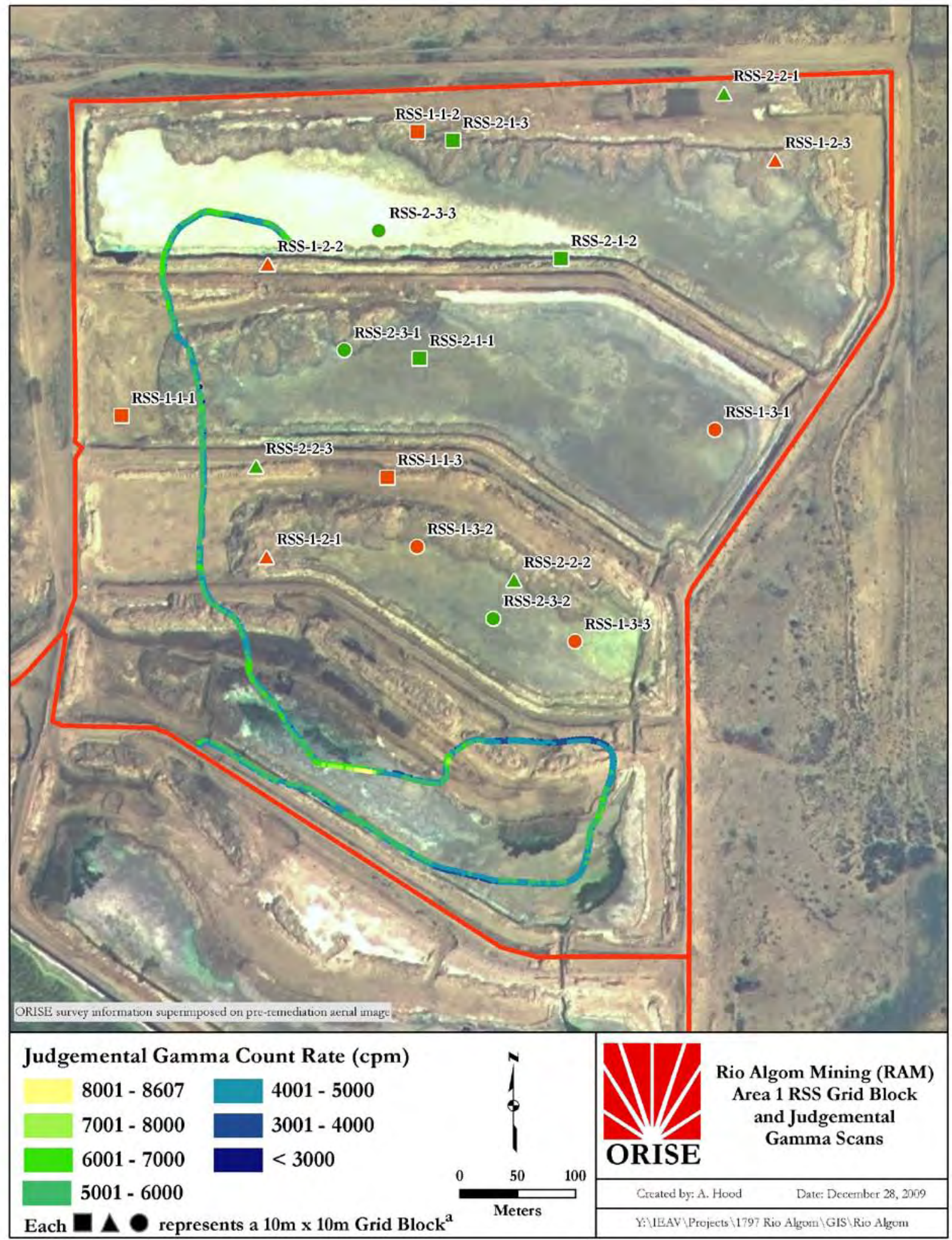

${ }^{\mathrm{a}} \mathrm{G}$ amma scan ranges for each RSS grid block provided in Table B-1.

Figure A-3: RAM Section 4 Ponds, Area 1 - Gamma Scans and Measurements 


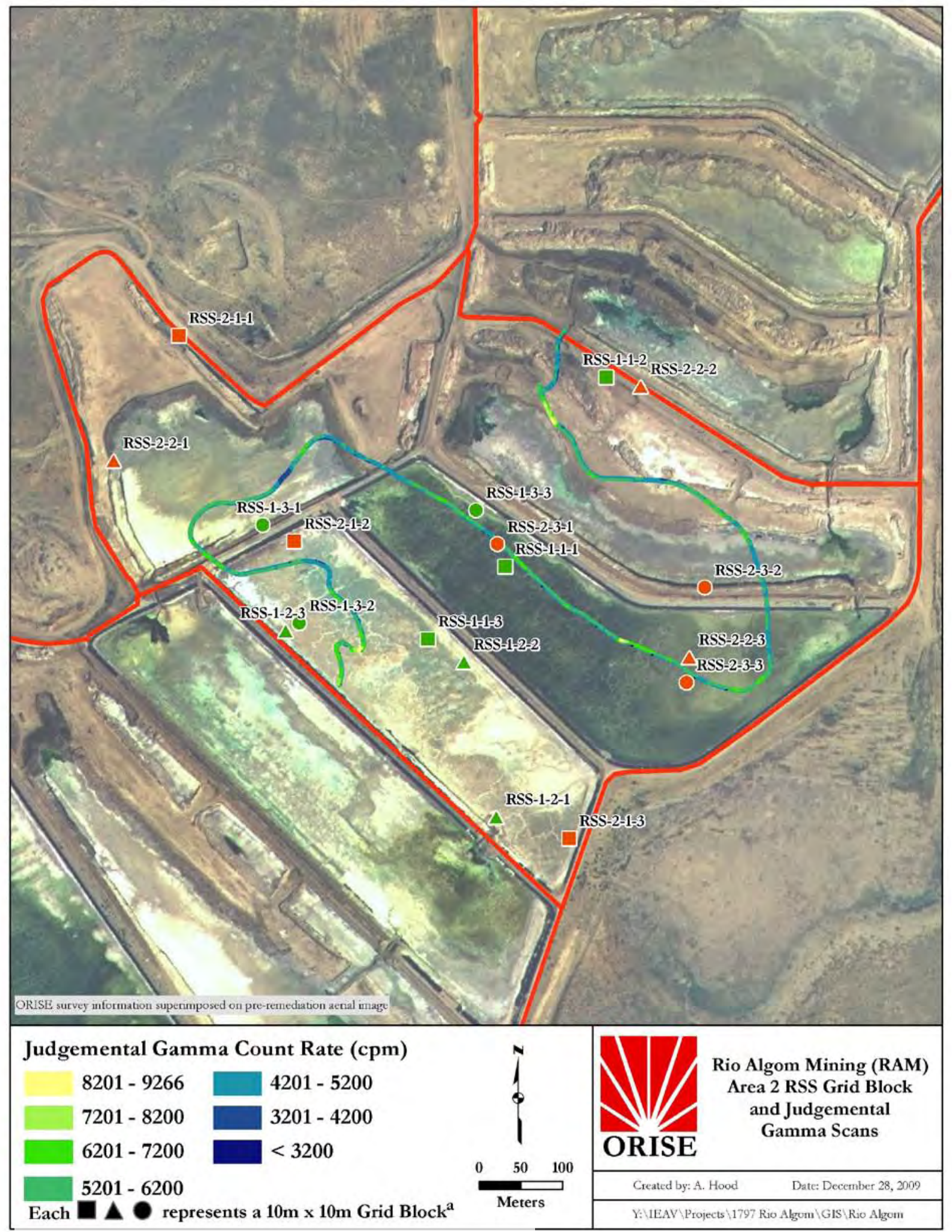

${ }^{a}$ Gamma scan ranges for each RSS grid block provided in Table B-1.

Figure A-4: RAM Section 4 Ponds, Area 2- Gamma Scans and Measurements 


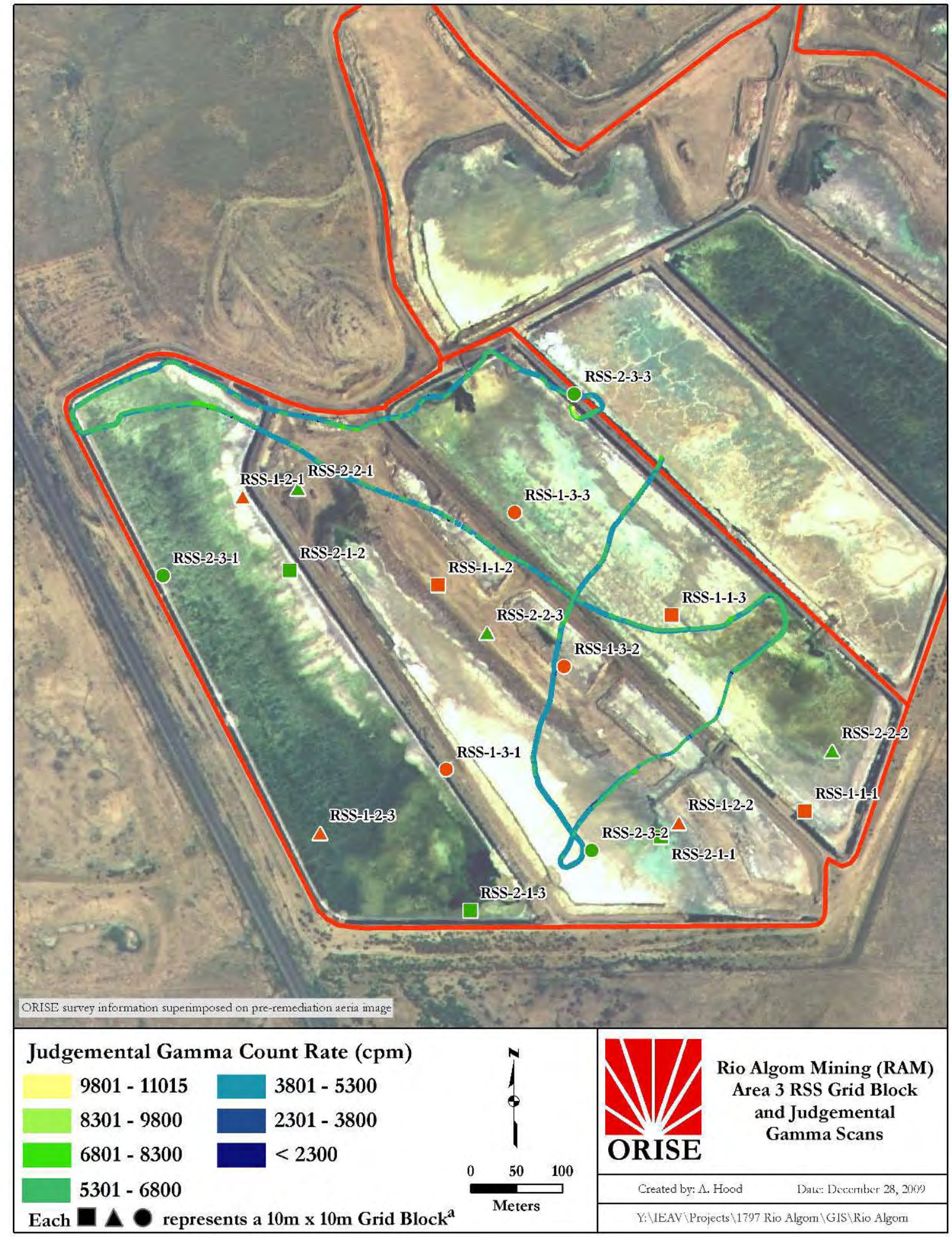

${ }^{a}$ Gamma scan ranges for each RSS grid block provided in Table B-1.

Figure A-5: RAM Section 4 Ponds, Area 3- Gamma Scans and Measurements 


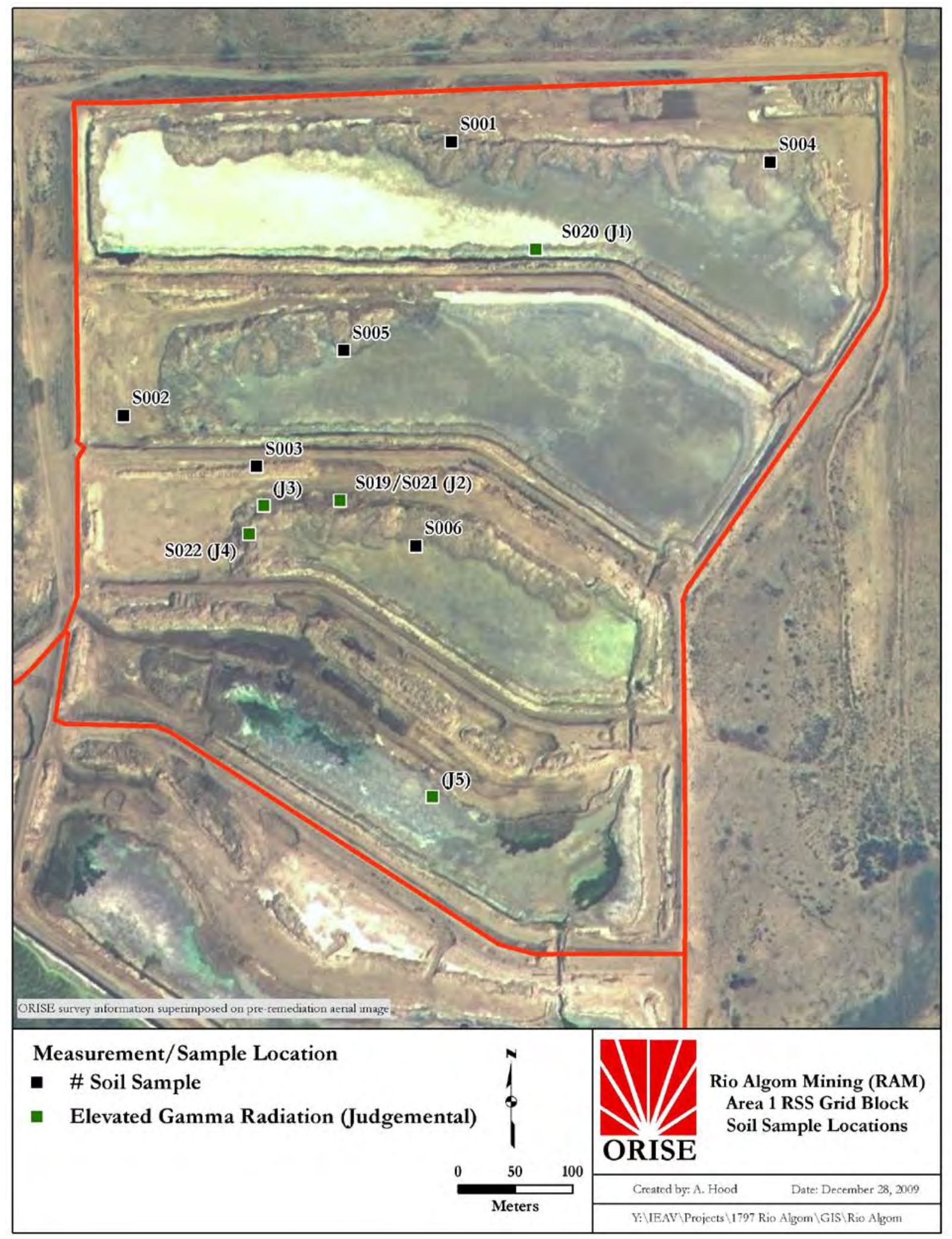

Figure A-6: RAM Section 4 Ponds, Area 1 - Elevated Gamma Radiation and Soil Sample Locations 


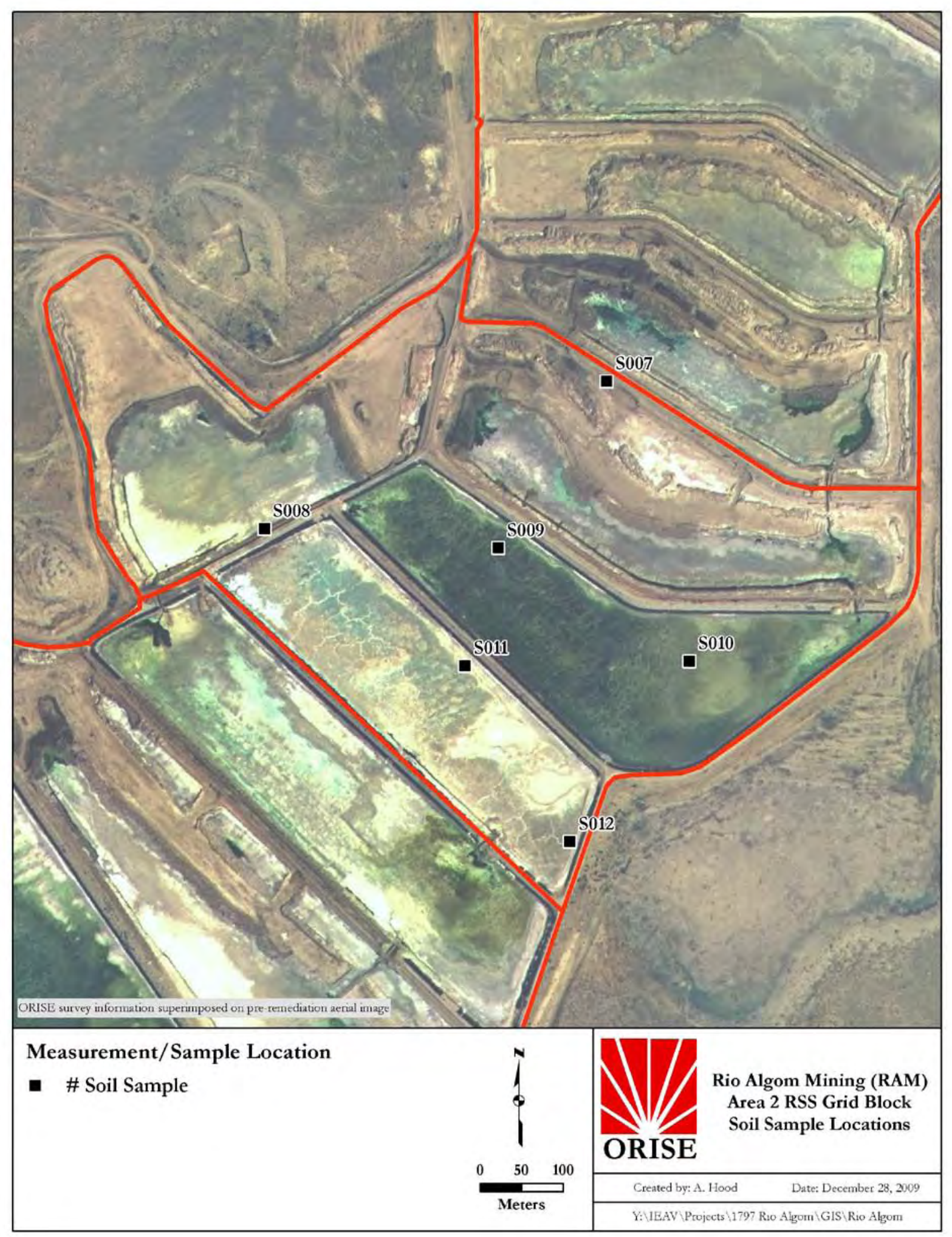

Figure A-7: RAM Section 4 Ponds, Area 2 - Soil Sample Locations 


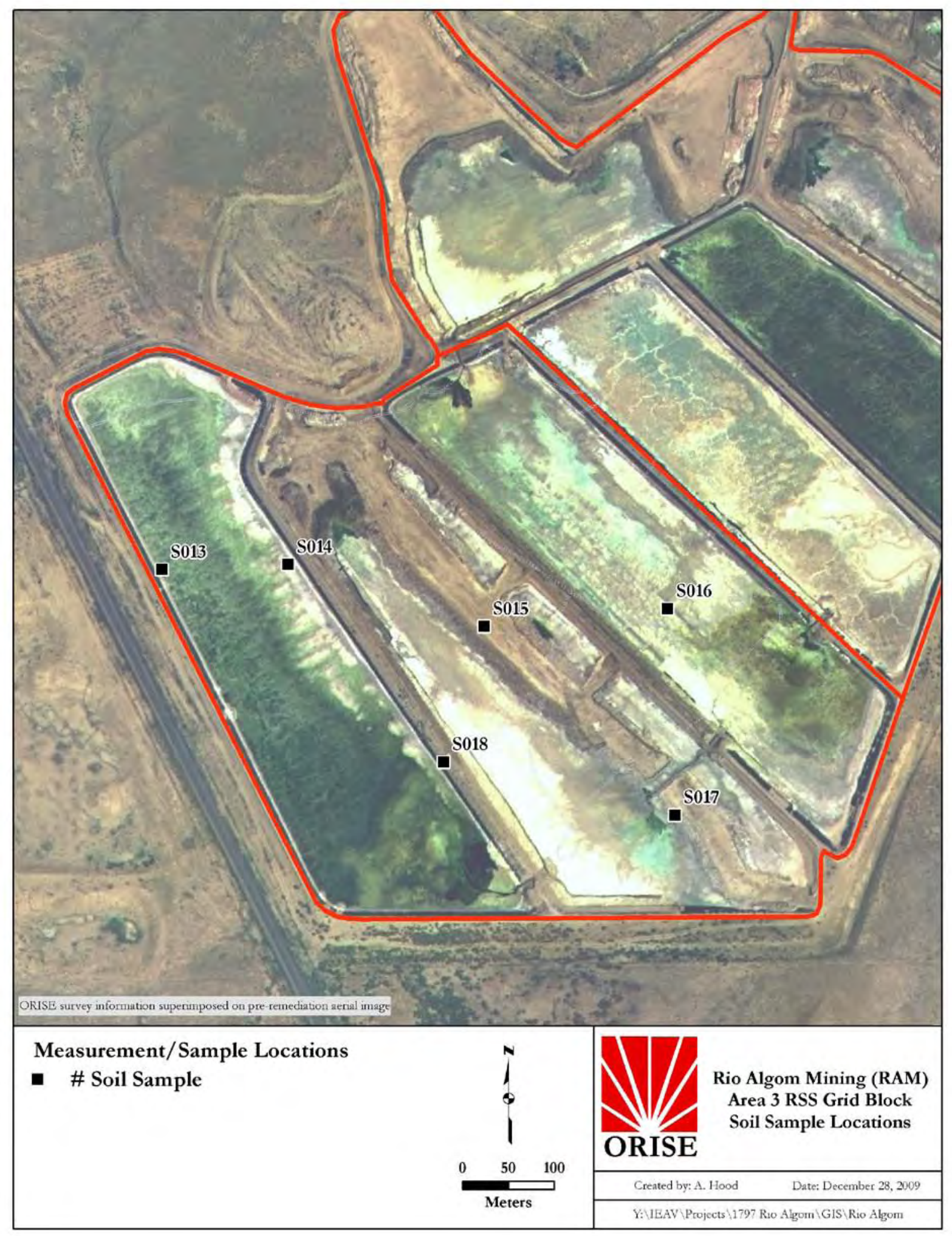

Figure A-8: RAM Section 4 Ponds, Area 3 - Soil Sample Locations 


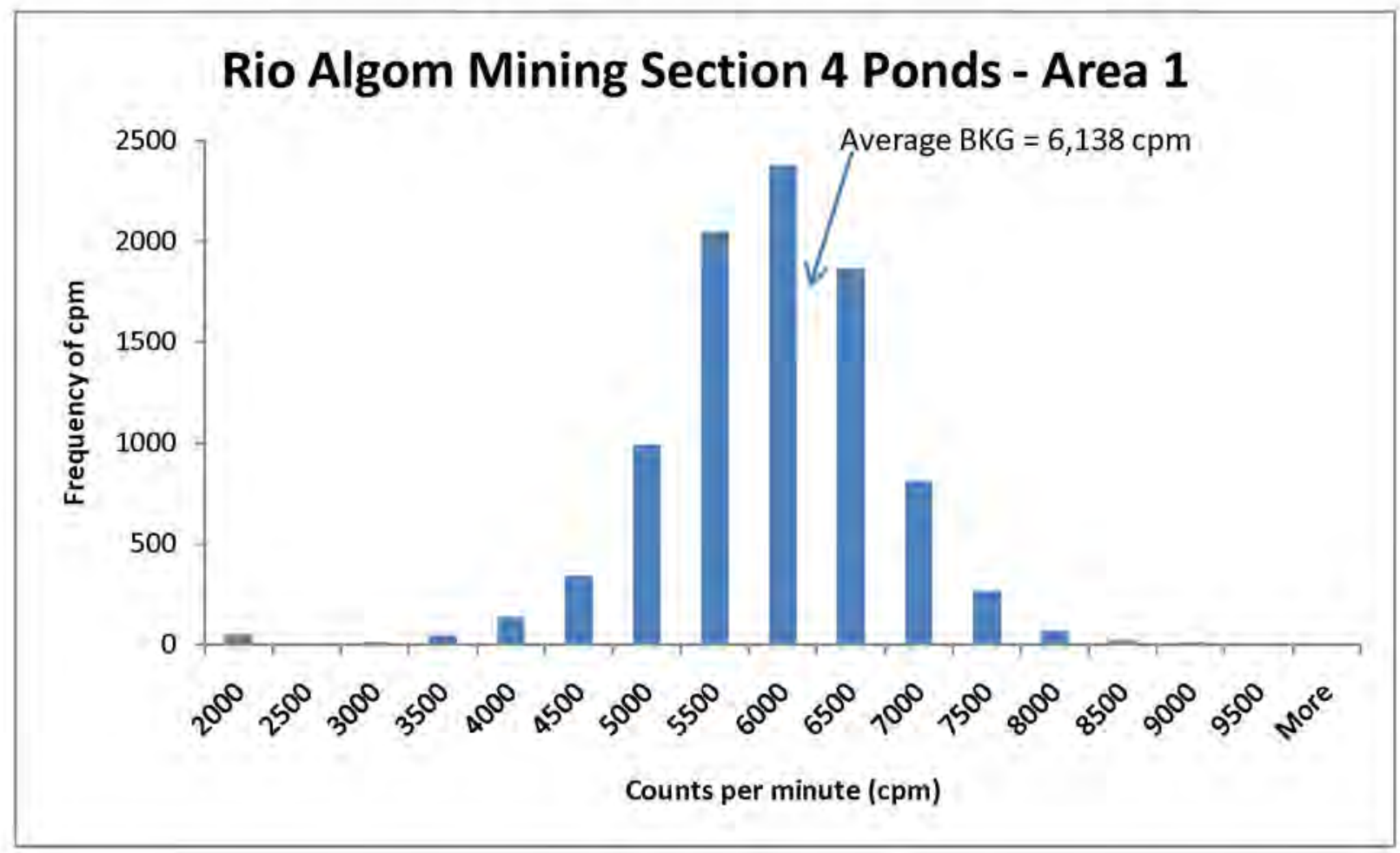

Figure A-9: RAM Section 4 Ponds, Area 1 - Judgmental Gamma Scan Count Rate Distribution

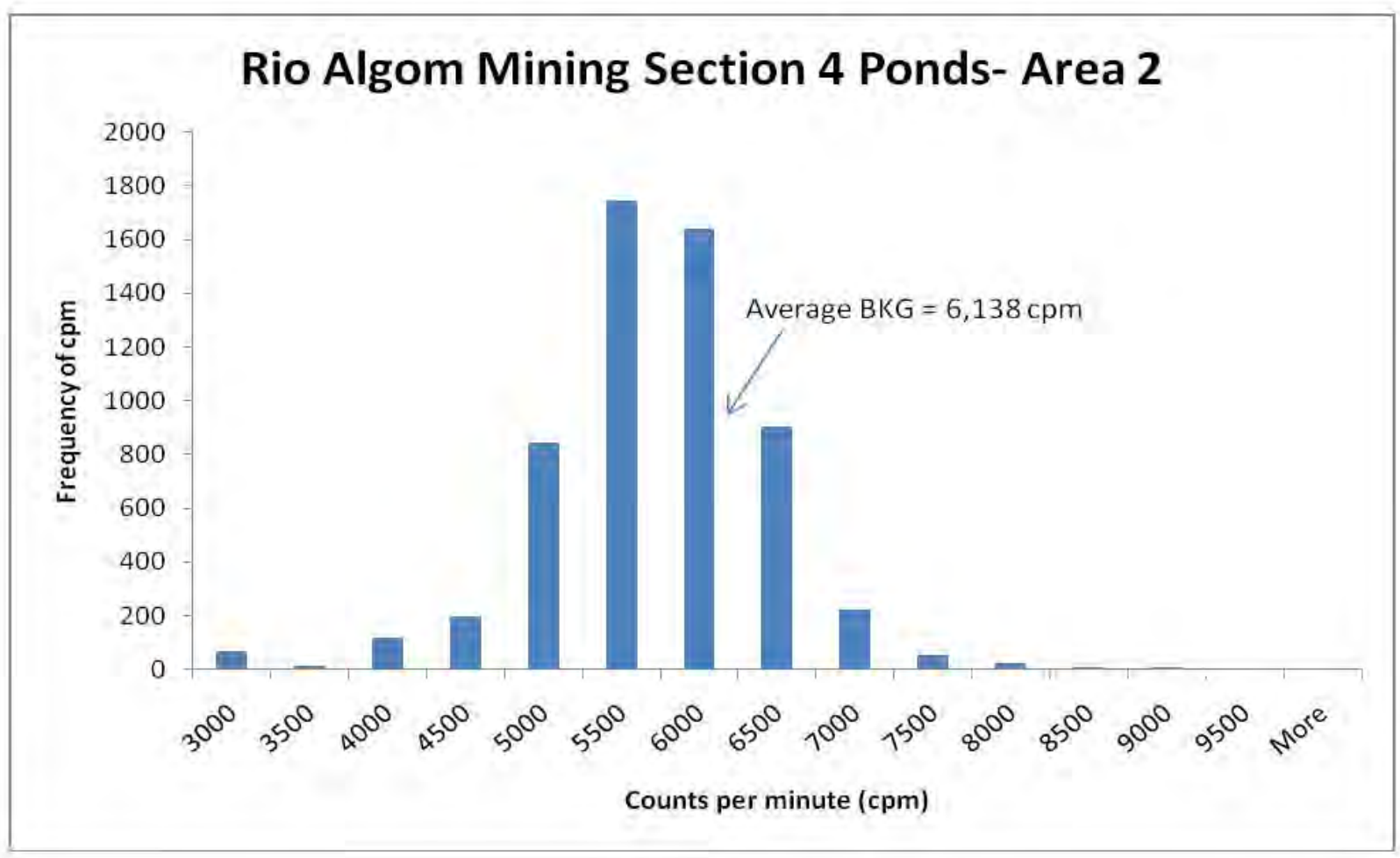

Figure A-10: RAM Section 4 Ponds, Area 2 - Judgmental Gamma Scan Count Rate Distribution 


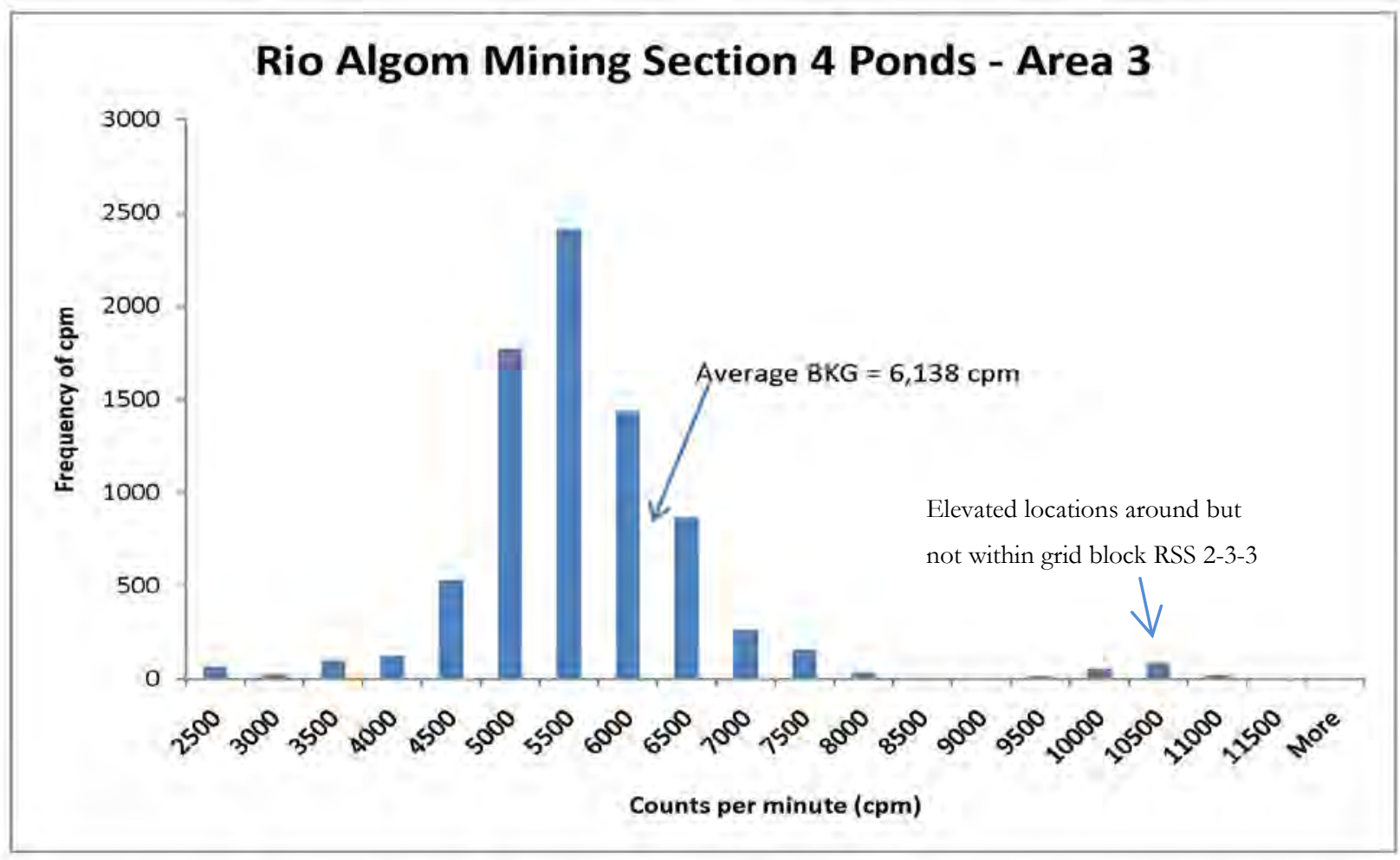

Figure A-11: RAM Section 4 Ponds, Area 3 - Judgmental Gamma Scan Count Rate Distribution 
APPENDIX B

TABLES 


\begin{tabular}{|c|c|c|c|c|c|c|c|c|c|}
\hline \multicolumn{10}{|c|}{$\begin{array}{c}\text { TABLE B-1: } \\
\text { RANKED SET SAMPLING GAMMA MEASUREMENTS } \\
\text { RIO ALGOM AMBROSIA LAKE FACILITY } \\
\text { AMBROSIA LAKE, NEW MEXICO }\end{array}$} \\
\hline \multirow{2}{*}{ East } & \multirow{2}{*}{ North } & \multicolumn{4}{|c|}{ RSS Measurement Location } & \multirow{2}{*}{$\begin{array}{l}\text { Grid Block } \\
\text { Gamma Scan } \\
\text { Range (cpm) }\end{array}$} & \multirow{2}{*}{$\begin{array}{c}\text { Gamma } \\
\text { Count }^{\mathrm{a}}\end{array}$} & \multirow{2}{*}{ Code $^{b}$} & \multirow{2}{*}{ Soil Sample \# } \\
\hline & & Cycle & Set & \# & Symbol & & & & \\
\hline \multicolumn{10}{|c|}{ Area $1^{c}$} \\
\hline 511908 & 1596698 & 1 & 1 & 1 & $\square$ & $--^{\mathrm{d}}$ & 10,236 & $\mathbf{L}$ & S002 \\
\hline 512749 & 1597505 & 1 & 1 & 2 & $\square$ & 4,030 to 7,967 & 10,517 & $\mathrm{~L}$ & \\
\hline 512663 & 1596522 & 1 & 1 & 3 & $\square$ & 5,035 to 7,047 & 11,281 & $\mathrm{~L}$ & \\
\hline 512321 & 1596295 & 1 & 2 & 1 & $\Delta$ & 5,368 to 7,355 & 11,906 & $\mathrm{M}$ & \\
\hline 512324 & 1597128 & 1 & 2 & 2 & $\Delta$ & 4,819 to 7,441 & 10,551 & M & \\
\hline 513766 & 1597422 & 1 & 2 & 3 & $\Delta$ & 4,959 to 6,903 & 10,772 & $\mathbf{M}$ & S004 \\
\hline 513595 & 1596658 & 1 & 3 & 1 & O & 4,107 to 6,341 & 9,543 & $\mathrm{H}$ & \\
\hline 512748 & 1596326 & 1 & 3 & 2 & 0 & 5,662 to 7,718 & 12,307 & $\mathbf{H}$ & S006 \\
\hline 513196 & 1596056 & 1 & 3 & 3 & 0 & 4,398 to 7,182 & 9,261 & $\mathrm{H}$ & \\
\hline 512755 & 1596861 & 2 & 1 & 1 & $\square$ & 4,223 to 8,571 & 10,283 & $\mathrm{~L}$ & \\
\hline 513157 & 1597145 & 2 & 1 & 2 & $\square$ & 4,971 to 7,358 & 10,928 & $\mathrm{~L}$ & \\
\hline 512850 & 1597480 & 2 & 1 & 3 & $\square$ & 4,699 to 7,567 & 10,052 & $\mathbf{L}$ & S001 \\
\hline 513620 & 1597612 & 2 & 2 & 1 & $\Delta$ & 4,460 to 7,229 & 10,133 & M & \\
\hline 513023 & 1596230 & 2 & 2 & 2 & $\Delta$ & 4,156 to 9,430 & 11,126 & $\mathrm{M}$ & \\
\hline 512290 & 1596553 & 2 & 2 & 3 & $\Delta$ & 4,800 to 7,383 & 11,116 & $\mathbf{M}$ & S003 \\
\hline 512541 & 1596884 & 2 & 3 & 1 & 0 & 2,450 to 7,087 & 11,498 & $\mathbf{H}$ & S005 \\
\hline 512965 & 1596122 & 2 & 3 & 2 & 0 & 4,747 to 7,658 & 10,530 & $\mathrm{H}$ & \\
\hline 512639 & 1597224 & 2 & 3 & 3 & 0 & 4,474 to 6,522 & 9,562 & $\mathrm{H}$ & \\
\hline
\end{tabular}




\begin{tabular}{|c|c|c|c|c|c|c|c|c|c|}
\hline \multirow{3}{*}{ East } & \multicolumn{8}{|c|}{$\begin{array}{l}\text { TABLE B-1: (continued) } \\
\text { SET SAMPLING GAMMA MEASUREMENTS } \\
\text { ALGOM AMBROSIA LAKE FACILITY } \\
\text { AMBROSIA LAKE, NEW MEXICO }\end{array}$} & \multirow{3}{*}{ Soil Sample \# } \\
\hline & \multirow{2}{*}{ North } & \multicolumn{4}{|c|}{ RSS Measurement Location } & \multirow{2}{*}{$\begin{array}{c}\text { Grid Block } \\
\text { Gamma Scan } \\
\text { Range (cpm) }\end{array}$} & \multirow{2}{*}{$\begin{array}{c}\text { Gamma } \\
\text { Count }^{\mathrm{a}}\end{array}$} & \multirow{2}{*}{ Code $^{b}$} & \\
\hline & & Cycle & Set & \# & Symbol & & & & \\
\hline \multicolumn{10}{|c|}{ Area $2^{\mathrm{e}}$} \\
\hline 511891 & 1594836 & 1 & 1 & 1 & $\square$ & 4,922 to 7,397 & 10,773 & $\mathrm{~L}$ & \\
\hline 512288 & 1595582 & 1 & 1 & 2 & $\square$ & 4,405 to 6,011 & 9,124 & $\mathbf{L}$ & S007 \\
\hline 511587 & 1594550 & 1 & 1 & 3 & $\square$ & -- & 9,846 & $\mathrm{~L}$ & \\
\hline 511855 & 1593849 & 1 & 2 & 1 & $\Delta$ & 3,858 to 7,056 & 11,187 & $\mathrm{M}$ & \\
\hline 511729 & 1594459 & 1 & 2 & 2 & $\Delta$ & 5,257 to 6,724 & 9,794 & $\mathbf{M}$ & S011 \\
\hline 511028 & 1594582 & 1 & 2 & 3 & $\Delta$ & 4,121 to 6,321 & 9,664 & $\mathrm{M}$ & \\
\hline 510937 & 1595000 & 1 & 3 & 1 & 0 & 4,451 to 6,804 & 10,678 & $\mathbf{H}$ & S008 \\
\hline 511081 & 1594614 & 1 & 3 & 2 & 0 & 4,458 to 6,307 & 9,725 & $\mathrm{H}$ & \\
\hline 511776 & 1595058 & 1 & 3 & 3 & 0 & 4,992 to 7,137 & 10,373 & $\mathrm{H}$ & \\
\hline 510607 & 1595745 & 2 & 1 & 1 & $\square$ & 4,646 to 6,528 & 9,926 & $\mathrm{~L}$ & \\
\hline 511061 & 1594935 & 2 & 1 & 2 & $\square$ & 4,401 to 6,565 & 9,891 & $\mathrm{~L}$ & \\
\hline 512143 & 1593765 & 2 & 1 & 3 & $\square$ & 4,403 to 6,565 & 9,798 & $\mathbf{L}$ & S012 \\
\hline 510351 & 1595252 & 2 & 2 & 1 & $\Delta$ & 4,021 to 6,493 & 8,907 & $\mathrm{M}$ & \\
\hline 512424 & 1595543 & 2 & 2 & 2 & $\Delta$ & 4,526 to 6,791 & 9,501 & $\mathrm{M}$ & \\
\hline 512615 & 1594477 & 2 & 2 & 3 & $\Delta$ & -- & 9,410 & $\mathbf{M}$ & S010 \\
\hline 511860 & 1594925 & 2 & 3 & 1 & 0 & 5,103 to 7,055 & 10,616 & $\mathbf{H}$ & S009 \\
\hline 512676 & 1594753 & 2 & 3 & 2 & O & 4,716 to 6,746 & 10,461 & $\mathrm{H}$ & \\
\hline 512604 & 1594380 & 2 & 3 & 3 & 0 & 4,470 to 6,490 & 9,188 & $\mathrm{H}$ & \\
\hline
\end{tabular}




\begin{tabular}{|c|c|c|c|c|c|c|c|c|c|}
\hline \multirow{3}{*}{ East } & \multicolumn{8}{|c|}{$\begin{array}{l}\text { TABLE B-1: (continued) } \\
\text { SET SAMPLING GAMMA MEASUREMENTS } \\
\text { ALGOM AMBROSIA LAKE FACILITY } \\
\text { AMBROSIA LAKE, NEW MEXICO }\end{array}$} & \multirow{3}{*}{ Soil Sample \# } \\
\hline & \multirow{2}{*}{ North } & \multicolumn{4}{|c|}{ RSS Measurement Location } & \multirow{2}{*}{$\begin{array}{c}\text { Grid Block } \\
\text { Gamma Scan } \\
\text { Range (cpm) } \\
\end{array}$} & \multirow{2}{*}{$\begin{array}{c}\text { Gamma } \\
\text { Count }^{a}\end{array}$} & \multirow{2}{*}{ Code $^{b}$} & \\
\hline & & Cycle & Set & \# & Symbol & & & & \\
\hline \multicolumn{10}{|c|}{ Area $3^{\mathrm{f}}$} \\
\hline 511746 & 1593113 & 1 & 1 & 1 & $\square$ & 2,738 to 6,307 & 9,342 & $\mathrm{~L}$ & \\
\hline 510437 & 1593919 & 1 & 1 & 2 & $\square$ & 4,235 to 6,386 & 9,407 & $\mathrm{~L}$ & \\
\hline 511271 & 1593812 & 1 & 1 & 3 & $\square$ & 3,286 to 6,123 & 9,320 & $\mathbf{L}$ & S016 \\
\hline 509739 & 1594232 & 1 & 2 & 1 & $\Delta$ & 4,698 to 6,387 & 9,685 & $\mathrm{M}$ & \\
\hline 511296 & 1593071 & 1 & 2 & 2 & $\Delta$ & -- & 10,425 & $\mathbf{M}$ & S017 \\
\hline 510016 & 1593034 & 1 & 2 & 3 & $\Delta$ & 3,604 to 6,881 & 10,777 & $\mathrm{M}$ & \\
\hline 510466 & 1593262 & 1 & 3 & 1 & 0 & 3,136 to 6,390 & 9,811 & $\mathbf{H}$ & S018 \\
\hline 510887 & 1593629 & 1 & 3 & 2 & 0 & 2,866 to 5,711 & 8,706 & $\mathrm{H}$ & \\
\hline 510711 & 1594177 & 1 & 3 & 3 & 0 & 4,160 to 6,524 & 9,273 & $\mathrm{H}$ & \\
\hline 511233 & 1593022 & 2 & 1 & 1 & 口 & 4,292 to 7,215 & 10,329 & $\mathrm{~L}$ & \\
\hline 509908 & 1593971 & 2 & 1 & 2 & 口 & 3,653 to 5,765 & 8,041 & $\mathbf{L}$ & S014 \\
\hline 510553 & 1592760 & 2 & 1 & 3 & 口 & 3,747 to 6,971 & 9,929 & $\mathrm{~L}$ & \\
\hline 509937 & 1594262 & 2 & 2 & 1 & $\triangle$ & 2,609 to 5,796 & 8,962 & M & \\
\hline 511843 & 1593327 & 2 & 2 & 2 & $\Delta$ & 3,103 to 7,066 & 10,661 & M & \\
\hline 510611 & 1593748 & 2 & 2 & 3 & $\triangle$ & 2,813 to 6,172 & 9,421 & $\mathbf{M}$ & S015 \\
\hline 509455 & 1593953 & 2 & 3 & 1 & 0 & 3,046 to 7,294 & 10,987 & $\mathbf{H}$ & S013 \\
\hline 510985 & 1592974 & 2 & 3 & 2 & 0 & 4,464 to 6,044 & 9,717 & $\mathrm{H}$ & \\
\hline 510923 & 1594600 & 2 & 3 & 3 & 0 & -- & 10,393 & $\mathrm{H}$ & \\
\hline
\end{tabular}

${ }^{a}$ Gamma counts represents the sum of the 4 individual 30 second gamma counts within each grid block.

${ }^{b}$ Sample select code specifies which location is sampled for a given cycle/set based on the gamma count rate.

cRefer to Figure A-3.

dGamma scan range not recorded.

eRefer to Figure A-4.

${ }^{\mathrm{f}} \mathrm{Refer}$ to Figure A-5.

Rio Algom Mining 


\section{TABLE B-2:}

RADIONUCLIDE CONCENTRATIONS IN SOIL SAMPLES

RIO ALGOM AMBROSIA LAKE FACILITY

AMBROSIA LAKE, NEW MEXICO

\begin{tabular}{|c|c|c|c|c|c|c|c|c|c|c|c|c|c|c|c|c|c|c|}
\hline \multirow[t]{2}{*}{ Sample \# } & \multicolumn{2}{|c|}{$\begin{array}{c}\text { Sample } \\
\text { Location }^{\text {a }}\end{array}$} & \multicolumn{15}{|c|}{ Radionuclide Concentrations (pCi/g) } & \multirow{2}{*}{$\mathrm{SOR}^{\mathrm{c}}$} \\
\hline & East & North & \multicolumn{3}{|c|}{ Th-230 } & \multicolumn{3}{|c|}{ Ra-226 } & \multicolumn{3}{|c|}{ U-235 } & & $\mathrm{J}-238$ & & \multicolumn{3}{|c|}{$\mathrm{NatU}^{\mathrm{b}}$} & \\
\hline \multicolumn{19}{|c|}{ Area 1} \\
\hline S001 & 512850 & 1597480 & 3.7 & \pm & $2.1^{\mathrm{d}}$ & 1.16 & & 0.07 & 0.46 & \pm & 0.06 & 10.28 & \pm & 0.72 & 21.0 & \pm & 1.6 & 0.94 \\
\hline S002 & 511908 & 1596698 & 92.8 & \pm & 7.1 & 2.39 & & 0.14 & 0.90 & \pm & 0.09 & 3.60 & \pm & 0.40 & 8.1 & \pm & 1.5 & 6.01 \\
\hline S003 & 512290 & 1596553 & 3.4 & \pm & 1.9 & 1.26 & & 0.08 & 0.09 & \pm & 0.04 & 1.34 & \pm & 0.19 & 2.8 & \pm & 1.4 & 0.45 \\
\hline S004 & 513766 & 1597422 & 7.7 & \pm & 2.2 & 1.16 & & 0.07 & 0.10 & \pm & 0.04 & 1.26 & \pm & 0.24 & 2.6 & \pm & 1.4 & 0.69 \\
\hline S005 & 512541 & 1596884 & 35.2 & \pm & 3.5 & 1.47 & - & 0.09 & 0.35 & \pm & 0.06 & 2.20 & \pm & 0.27 & 4.8 & \pm & 1.4 & 2.41 \\
\hline S006 & 512748 & 1596326 & 11.7 & \pm & 2.7 & 1.54 & & 0.10 & 0.10 & \pm & 0.07 & 1.75 & \pm & 0.30 & 3.6 & \pm & 1.4 & 1.00 \\
\hline \multicolumn{3}{|c|}{ Area 1 Mean Concentrations } & \multicolumn{3}{|c|}{25.75} & \multicolumn{3}{|c|}{1.50} & \multicolumn{3}{|c|}{0.33} & \multicolumn{3}{|c|}{3.41} & \multicolumn{3}{|c|}{7.14} & 1.92 \\
\hline \multicolumn{19}{|c|}{ Area 2} \\
\hline S007 & 512288 & 1595582 & 3.8 & \pm & 1.1 & 0.87 & & 0.06 & 0.08 & \pm & 0.03 & 0.88 & \pm & 0.12 & 1.8 & \pm & 1.4 & 0.40 \\
\hline S008 & 510937 & 1595000 & 26.3 & \pm & 2.5 & 1.17 & - & 0.07 & 0.30 & \pm & 0.04 & 2.99 & \pm & 0.27 & 6.3 & \pm & 1.4 & 1.88 \\
\hline S009 & 511860 & 1594925 & 0.3 & \pm & 3.3 & 1.17 & & 0.09 & 0.08 & \pm & 0.04 & 1.11 & \pm & 0.17 & 2.3 & \pm & 1.4 & 0.25 \\
\hline S010 & 512615 & 1594477 & 3.9 & \pm & 1.6 & 0.92 & 1 & 0.06 & 0.09 & \pm & 0.04 & 1.39 & \pm & 0.20 & 2.9 & \pm & 1.4 & 0.44 \\
\hline S011 & 511729 & 1594459 & 16.5 & \pm & 1.8 & 1.15 & & 0.07 & 0.22 & \pm & 0.03 & 1.98 & \pm & 0.19 & 4.2 & \pm & 1.4 & 1.24 \\
\hline S012 & 512143 & 1593765 & 2.9 & \pm & 1.3 & 0.88 & 1 & 0.06 & 0.35 & \pm & 0.04 & 6.41 & \pm & 0.46 & 13.2 & \pm & 1.5 & 0.64 \\
\hline \multicolumn{3}{|c|}{ Area 2 Mean Concentrations } & \multicolumn{3}{|c|}{8.95} & \multicolumn{3}{|c|}{1.03} & \multicolumn{3}{|c|}{0.19} & \multicolumn{3}{|c|}{2.46} & \multicolumn{3}{|c|}{5.11} & 0.81 \\
\hline \multicolumn{19}{|c|}{ Area 3} \\
\hline S013 & 509455 & 1593953 & 58.3 & \pm & 4.7 & 1.74 & - & 0.12 & 0.57 & \pm & 0.06 & 2.89 & \pm & 0.28 & 6.4 & \pm & 1.4 & 3.85 \\
\hline S014 & 509908 & 1593971 & 3.4 & \pm & 1.5 & 0.80 & 1 & 0.05 & 0.05 & \pm & 0.04 & 1.11 & \pm & 0.18 & 2.3 & \pm & 1.4 & 0.37 \\
\hline S015 & 510611 & 1593748 & 6.5 & \pm & 1.3 & 0.97 & 1 & 0.06 & 0.10 & \pm & 0.03 & 1.17 & \pm & 0.14 & 2.4 & \pm & 1.4 & 0.59 \\
\hline S016 & 511271 & 1593812 & 7.4 & \pm & 1.5 & 0.95 & - & 0.07 & 0.10 & \pm & 0.03 & 1.25 & \pm & 0.17 & 2.6 & \pm & 1.4 & 0.64 \\
\hline S017 & 511296 & 1593071 & 1.2 & \pm & 4.2 & 1.46 & $I$ & 0.09 & 0.13 & \pm & 0.04 & 3.10 & \pm & 0.30 & 6.3 & \pm & 1.4 & 0.45 \\
\hline
\end{tabular}


TABLE B-2: (continued)

RADIONUCLIDE CONCENTRATIONS IN SOIL SAMPLES

RIO ALGOM AMBROSIA LAKE FACILITY

AMBROSIA LAKE, NEW MEXICO

\begin{tabular}{|c|c|c|c|c|c|c|c|c|c|c|}
\hline \multirow[t]{2}{*}{ Sample \# } & \multicolumn{2}{|c|}{$\begin{array}{c}\text { Sample } \\
\text { Location }^{\text {a }}\end{array}$} & \multicolumn{7}{|c|}{ Radionuclide Concentrations (pCi/g) } & \multirow[t]{2}{*}{ SOR $^{\mathrm{c}}$} \\
\hline & East & North & & & Ra-226 & U-235 & $\mathrm{U}-238$ & & $\mathrm{Nat}^{\mathrm{b}}$ & \\
\hline \multicolumn{11}{|c|}{ Area 3 (Continued) } \\
\hline S018 & 510466 & 1593262 & 1.6 & 1.4 & $1.06 \pm 0.09$ & $0.15 \pm 0.04$ & $2.62 \pm 0.26$ & 5.4 & 1.4 & 0.39 \\
\hline \multicolumn{3}{|c|}{ Area 3 Mean Concentrations } & \multicolumn{2}{|c|}{13.07} & 1.16 & 0.18 & 2.02 & \multicolumn{2}{|r|}{4.23} & 1.05 \\
\hline \multicolumn{3}{|c|}{$\begin{array}{c}\text { Section } 4 \text { Ponds Mean } \\
\text { Concentration }\end{array}$} & \multicolumn{2}{|c|}{15.92} & 1.23 & 0.23 & 2.63 & \multicolumn{2}{|r|}{5.49} & 1.26 \\
\hline
\end{tabular}

Elevated Areas as Determined by Gamma Scans

\begin{tabular}{|c|c|c|c|c|c|c|c|c|c|c|c|c|c|c|c|c|c|c|}
\hline S019 & 512530 & 1596456 & 1500 & \pm & 100 & 18.1 & & 1.0 & $1.95^{\circ}$ & & 0.14 & 7.2 & & 1.7 & $16.4^{\mathrm{e}}$ & & 2.2 & 91.25 \\
\hline S020 & 513083 & 1597176 & 923 & & 65 & 21.5 & 1 & 1.2 & $2.01^{\circ}$ & - & 0.13 & 26.7 & - & 2.4 & $55.4^{\mathrm{e}}$ & & 2.8 & 58.82 \\
\hline \multicolumn{19}{|c|}{ Elevated Areas after Remediation by Licensee } \\
\hline S021 & 512530 & 1596456 & 12.3 & 1 & 1.7 & 1.53 & \pm & 0.09 & 0.34 & - & 0.04 & 1.61 & - & 0.19 & 3.6 & & 1.4 & 1.04 \\
\hline S022 & 512269 & 1596360 & 3.2 & \pm & 2.7 & 0.78 & \pm & 0.06 & 0.10 & \pm & 0.04 & 0.89 & \pm & 0.15 & 1.9 & \pm & 1.4 & 0.35 \\
\hline
\end{tabular}

aRefer to Figures A-6 through A-8.

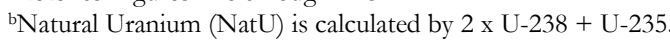

cSOR = Sum of Ratios.

dUncertainties are total propagated uncertainties, based on the $95 \%$ confidence interval.

eDue to the presence of radionuclides (Th-227 and Ra-226) that emit gammas which interfere with the 143 and $186 \mathrm{keV}$ peaks of U-235, the U-235 and NatU values may be overestimated for these two samples.

The $186 \mathrm{keV}$ peak for $\mathrm{U}-235$ was used for this calculation. 
APPENDIX C

MAJOR INSTRUMENTATION 


\section{APPENDIX C \\ MAJOR INSTRUMENTATION}

The display of a specific product is not to be construed as an endorsement of the product or its manufacturer by the author or his employer.

\section{SCANNING AND MEASUREMENT INSTRumEnt/Detector Combinations}

\section{$\underline{\text { Gamma }}$}

Victoreen NaI Scintillation Detector Model 489-55, Crystal: $3.2 \mathrm{~cm}$ x $3.8 \mathrm{~cm}$

(Victoreen, Cleveland, $\mathrm{OH}$ )

coupled to:

Ludlum Ratemeter-scaler Model 2221

(Ludlum Measurements, Inc., Sweetwater, TX)

coupled to:

Trimble GeoXH Receiver and Data Logger (Trimble Navigation Limited, Sunnyvale, CA)

\section{Laboratory Analytical Instrumentation}

High Purity Extended Range Intrinsic Detector

CANBERRA/Tennelec Model No: ERVDS30-25195

(Canberra, Meriden, CT)

Used in conjunction with:

Lead Shield Model G-11

(Nuclear Lead, Oak Ridge, TN) and

Multichannel Analyzer

Canberra's Apex Gamma Software

Dell Workstation

(Canberra, Meriden, CT)

High Purity Extended Range Intrinsic Detector

Model No. GMX-45200-5

(AMETEK/ORTEC, Oak Ridge, TN)

used in conjunction with:

Lead Shield Model SPG-16-K8

(Nuclear Data)

Multichannel Analyzer

Canberra's Apex Gamma Software

Dell Workstation

(Canberra, Meriden, CT) 
Laboratory Analytical Instrumentation (continued)

High-Purity Germanium Detector

Model GMX-30-P4, 30\% Eff.

(AMETEK/ORTEC, Oak Ridge, TN)

Used in conjunction with:

Lead Shield Model G-16

(Gamma Products, Palos Hills, IL) and

Multichannel Analyzer

Canberra's Apex Gamma Software

Dell Workstation

(Canberra, Meriden, CT) 
APPENDIX D

SURVEY AND ANALYTICAL PROCEDURES 


\section{APPENDIX D \\ SURVEY AND ANALYTICAL PROCEDURES}

\section{Project Health and SAFety}

The proposed survey and sampling procedures were evaluated to ensure that any hazards inherent to the procedures themselves were addressed in current job hazard analyses (JHA). All survey and laboratory activities were conducted in accordance with ORISE health and safety and radiation protection procedures.

Pre-survey activities included the evaluation and identification of potential health and safety issues. Survey work was performed per the ORISE generic health and safety plans and a site-specific integrated safety management (ISM) pre-job hazard checklist. Rio Algom personnel also provided site-specific safety awareness training.

\section{Calibration AND Quality Assurance}

Calibration of all field and laboratory instrumentation was based on standards/sources, traceable to the National Institute of Standards and Technology (NIST).

Analytical and field survey activities were conducted in accordance with procedures from the following ORAU and ORISE documents:

- $\quad$ Survey Procedures Manual (May 2008)

- $\quad$ Laboratory Procedures Manual (June 2009)

- Quality Program Manual (June 2009)

The procedures contained in these manuals were developed to meet the requirements of $10 \mathrm{CFR}$ 830 Subpart A, Quality Assurance Requirements, Department of Energy Order 414.1C Quality Assurance, and the U.S. Nuclear Regulatory Commission Quality Assurance Manual for the Office of Nuclear Material Safety and Safeguards and contain measures to assess processes during their performance. 
Quality control procedures include:

- Daily instrument background and check-source measurements to confirm that equipment operation is within acceptable statistical fluctuations.

- Participation in Mixed-Analyte Performance Evaluation Program (MAPEP), NIST

Radiochemistry Intercomparison Testing Program (NRIP), and Intercomparison Testing

Program (ITP) Laboratory Quality Assurance Programs.

- Training and certification of all individuals performing procedures.

- Periodic internal and external audits.

\section{SuRVEY Procedures}

\section{$\underline{\text { Surface Scans }}$}

A NaI scintillation detector was used to scan for elevated gamma radiation. Identification of elevated radiation levels was based on increases in the audible signal from the recording and/or indicating instrument. Additionally, the detectors were coupled to GPS units with data loggers enabling real-time recording in one-second intervals of both geographic position and the gamma count rate. Positioning data files were downloaded from field data loggers for plotting using commercially available software (http://trl.trimble.com/docushare/dsweb/Get/Document261826/GeoExpl2005 100A GSG ENG.pdf). Position and gamma count rate data files were transferred to a computer system, positions differentially corrected, and the results plotted on geo-referenced aerial photographs. Positional accuracy was within 0.5 meters at the $95^{\text {th }}$ percentile.

The scan minimum detectable concentrations for the $\mathrm{NaI}$ scintillation detectors were 3,000 $\mathrm{pCi} / \mathrm{g}$ for Th-230, $115 \mathrm{pCi} / \mathrm{g}$ for natural uranium, and $4.5 \mathrm{pCi} / \mathrm{g}$ for Ra-226, as provided in NUREG-1507. An audible increase in the activity rate was investigated by ORISE. It is standard procedure for the ORISE staff to pause and investigate any locations where gamma radiation is distinguishable from background levels.

\section{Soil Sampling}

Approximately 0.5 to $1 \mathrm{~kg}$ of soil was collected at each sample location. Collected samples were placed in a plastic bag, sealed, and labeled in accordance with ORISE survey procedures. 
The judgmental soil samples were collected as individual samples from an area of elevated gamma radiation based on gamma scans. The RSS grid blocks (100 $\mathrm{m}^{2}$ areas) samples were collected as follows: four surface soil samples (0 to $15 \mathrm{~cm}$ ) were collected from four points midway between the center and $100 \mathrm{~m}^{2}$ grid block corners. These four samples were field composited into one soil sample from that $100 \mathrm{~m}^{2}$ area grid block.

\section{RADIOLOGICAL ANALYSIS}

\section{Gamma Spectroscopy}

Samples of soil were dried, mixed, crushed, and/or homogenized as necessary, and a portion sealed in a 0.5 -liter Marinelli beaker or other appropriate container. The quantity placed in the beaker was chosen to reproduce the calibrated counting geometry. Net material weights and volumes were determined and the samples counted using intrinsic germanium detectors coupled to a pulse height analyzer system. Background and Compton stripping, peak search, peak identification, and concentration calculations were performed using the computer capabilities inherent in the analyzer system. All total absorption peaks (TAP) associated with the ROCs were reviewed for consistency of activity. TAPs used for determining the activities of ROCs and the typical associated minimum detectable concentration (MDCs) for a four-hour count time were:

\begin{tabular}{|c|c|c|}
\hline Radionuclide & TAP $^{a}(\mathbf{M e V})$ & MDC (pCi/g) \\
\hline \hline Th-230 & 0.067 & 5.09 \\
\hline Ra-226 by Pb-214 & 0.351 & 0.04 \\
\hline U-235 & 0.143 & 0.12 \\
\hline U-238 by Th-234 & 0.063 & 0.49 \\
\hline
\end{tabular}

aSpectra were also reviewed for other identifiable TAPs that would not be expected at this site.

\section{Uncertainties}

The uncertainties associated with the analytical data presented in the tables of this report represent the total propagated uncertainties for that data. These uncertainties were calculated based on both the gross sample count levels and the associated background count levels. 


\section{DETECTION Limits}

Detection limits, referred to as minimum detectable concentrations, were based on 3 plus 4.65 times the standard deviation of the background count $\left[3+\left(4.65(\mathrm{BKG})^{1 / 2}\right)\right]$. Because of variations in

background levels, measurement efficiencies, and contributions from other radionuclides in samples, the detection limits differ from sample to sample and instrument to instrument. 


\section{APPENDIX E \\ ORISE STATISTICAL SURVEY DESIGN FOR THE \\ SECTION 4 PONDS AT THE \\ RIO ALGOM MINING FACILITY \\ AMBROSIA LAKE, NEW MEXICO}




\section{APPENDIX E}

\section{ORISE STATISTICAL SURVEY DESIGN FOR THE SECTION 4 PONDS AT THE RIO ALGOM MINING FACILITY AMBROSIA LAKE, NEW MEXICO}

\section{SURVEY DESIGN SUMMARY}

ORISE used available pre-final status survey data to develop a defensible statistical sampling and survey design for the Section 4 Ponds at the Rio Algom Ambrosia Lake Facility. The selected VSP statistical approach, as set forth in U.S. Environmental Protection Agency (EPA) QA/G-5S, calculates the number of samples required to determine a confidence interval for the mean that meets the boundaries provided by the user. A RSS design was selected using associated statistical assumptions as well as general guidelines for conducting post-sampling data analysis. The sampling plan components included how many sampling locations to choose and where within the sampling area to collect those samples.

The following table summarizes the balanced ranked set sampling design developed.

\begin{tabular}{|c|c|}
\hline \multicolumn{2}{|c|}{ SUMMARY OF SAMPLING DESIGN FOR EACH AREA } \\
\hline Primary Objective of Design & Estimate the population mean \\
\hline $\begin{array}{l}\text { Sample Placement (Location) } \\
\text { in the Field }\end{array}$ & Simple random sampling \\
\hline $\begin{array}{l}\text { Formula for calculating } \\
\text { number of sampling locations }\end{array}$ & $\begin{array}{l}\text { Balanced ranked set sampling equations } \\
\text { in EPA QA/G-5S (EPA, 2001) }\end{array}$ \\
\hline $\begin{array}{l}\text { Number of Ranks (m) } \\
\text { (Chosen Set Size) }\end{array}$ & 3 \\
\hline Calculated Number of Cycles (r) & 2 \\
\hline $\begin{array}{l}\text { Number of Samples to Analyze } \\
(\mathrm{m} \times \mathrm{r})\end{array}$ & 6 \\
\hline $\begin{array}{l}\text { Number of Field Locations to Rank } \\
(\mathrm{m} \times \mathrm{m} \times \mathrm{r})\end{array}$ & 18 \\
\hline Number of selected sample areas $^{{ }^{a}}$ & 3 \\
\hline Specified sampling area ${ }^{b}$ & $13020216 \mathrm{ft}^{2}$ \\
\hline
\end{tabular}

Figure E-1 demonstrates the VSP measurement locations in the field. There were 18 measurement locations within each survey area from which six samples were collected from each area. 


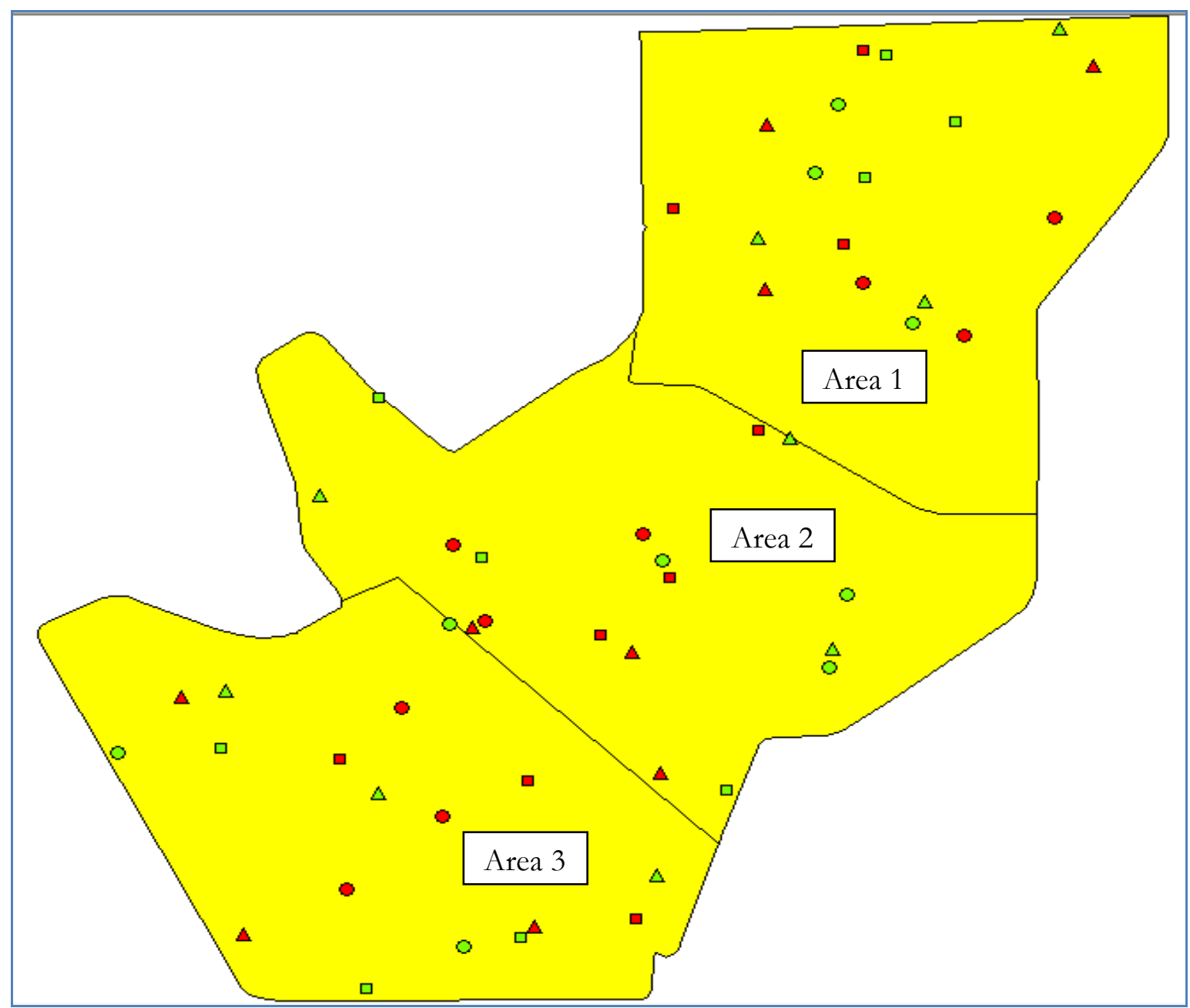

Figure E-1: Visual Sample Plan Generated Measurement Locations for the 3 Survey Areas

Table B-1 lists the sampling coordinates generated by VSP that were identified in the field.

The following VSP report was generated using site inputs and is as follows: RSS involves selecting a set of field locations using simple random sampling, then dividing the locations into subsets (called "sets"). Then either professional judgment (expert opinion) or a quantitative inexpensive field measurement method is used in the field to rank (order) the locations within each set with respect to the variable being measured. Then, within each set, only one location among the ranked locations is selected to be sampled for laboratory analysis. The method used to determine the number of locations that need to be ranked and the number of locations that need to be sampled for measurement in the laboratory is described in EPA QA/G-5S (EPA 2002).

RSS was chosen because that design was found to be more cost effective for estimating the mean than simple random sampling. It is expected to yield a narrower confidence interval for the mean than a simple random sampling design with the same number of laboratory analyzed samples. RSS sampling design can achieve cost savings by implementing relatively inexpensive qualitative (expert opinion and/or professional judgment) or quantitative field screening techniques in association with more expensive laboratory analytical measurements of samples. Additionally, RSS provides an unbiased estimate of the mean and can yield an increased ability to detect differences in the parameters of different populations (e.g., site and background areas). 
The assumptions that underlie RSS are expected to be valid and will be examined in post-sampling data analysis. There are some limitations associated with ranked set sampling. The increased precision of the estimated mean obtained using ranked set sampling compared to simple random sampling is reduced if errors are made in ranking field locations. However, even when ranking errors occur, RSS is never expected to be less precise than if simple random sampling with the same number of measurements is used. Another limitation is that ranked set sampling may not be more cost effective than simple random sampling if field locations are clustered in space rather than selected randomly. In addition, computations needed to conduct some statistical analyses such as tests of hypotheses using data obtained from RSS are different that the standard computations used when sample locations are selected using simple random sampling. Hence, statistical expertise may be needed to determine the appropriate calculations. Finally, information collected from the ranking process, including any quantitative measurements that are used to conduct the ranking, is not used to calculate the mean (EPA 2002).

\section{Determination Of Number Of Data Points}

\section{Number of Total Samples: Calculation Equation and Inputs}

The number of samples is calculated by following the process for RSS outlined in EPA QA/G-5S. This process has been detailed in the following discussions of the points. The following steps outline the user inputs and calculations conducted within VSP to determine the RSS design.

1. Determine the number of samples required under simple random sampling, $n_{0}$

2. $\quad$ Select the "set size", $m$

3. Determine the relative precision $(R P)$ of simple random sampling compared to ranked set sampling

4. Compute the number of cycles, $r$, of RSS that are required

5. Compute the total number of ranked set samples, $n$, that should be collected and measured to estimate the mean

\section{Determine the number of samples required under simple random sampling, $n_{o}$;}

In order to determine the number of samples to collect if simple random sampling were used, $n_{o}$, VSP requires the user to specify whether the distribution of measurements resulting from laboratory samples is expected to be symmetric or skewed to the right (a long right tail). If the expected distribution is symmetric, then a balanced ranked set sampling design will be used and the number of samples is calculated by VSP using either a one-sided or a two-sided confidence interval equation, as selected by the VSP user. If the expected distribution is skewed to the right, then an unbalanced ranked set sampling design will be used and the number of samples is computed using the method outlined by Perez and Lefante (1997).

The equation used to calculate $n_{0}$ for the balanced RSS case is the same as VSP uses to compute the number of samples required for computing a two-sided confidence interval for the mean when simple random sampling is used. The calculated number of samples, $n_{o}$, using simple random sampling will result in a confidence interval that has a half-width that does not exceed the maximum acceptable half-width specified by the VSP user.

For a two-sided confidence interval, the equation used to calculate the number of samples under simple random sampling, $n_{o}$, when the expected distribution is symmetric and a balanced ranked set sampling design is used is: 


$$
n_{o}=s^{2}\left(\frac{t_{1-\alpha / 2, d f}}{d}\right)^{2}
$$

Where,

$n_{0} \quad$ is the recommended minimum number of samples for the study area if simple random sampling were used,

$s \quad$ is the estimated standard deviation of measurements of collected samples,

$d \quad$ is the maximum desired half-width of the confidence interval,

$t_{1-\alpha / 2, \mathrm{df}}$ is the value of the Student's t-distribution with $n-1$ degrees of freedom (df) such that the proportion of that distribution less than $t_{1-\alpha / 2, \mathrm{df}}$ is $1-a / 2$

Because $n$ appears on both sides of the above equation (on the right side it appears in the degrees of freedom of the $t$ distribution), the equation must be solved iteratively. VSP does this automatically using the iteration scheme in Gilbert (1987, pg. 32).

\section{Select the "set size", $m$;}

The set size, $m$, is an integer between 2 and 8 selected by the VSP user. When a balanced RSS design is used, $m$ is the number of field locations sampled in each cycle of RSS. The number of cycles is denoted by $r$. Hence, the total number of locations sampled when balanced ranked set sampling is used is $n=m \times r$. The value of $m$ selected is usually based on practical constraints in ranking locations by professional judgment or quantitative field measurements. If professional judgment is used to rank potential field locations, G-5S recommends setting $m<=5$ due to the potential lack of accuracy in ranking by professional judgment. If field quantitative measurements are used to rank potential locations, then the ranking may be accurate for larger values of $\mathrm{m}$.

\section{Determine the $R P s$ of simple random sampling compared to ranked set sampling;}

The estimated RPs is the estimated variance of the mean if simple random sampling is used divided by the estimated variance of the mean if ranked set sampling is used. When a balanced ranked set sampling design is used, VSP uses the RPs published by Patil et al. (1994, Table 1) for the normal distribution. The RPs depends only on the set size, $m$, specified by the VSP user. (If an unbalanced ranked set sampling design is used, then VSP uses a more complicated process to determine the RP, as described in EPA QA/G-5S.)

\section{Compute the number of cycles, $t$, of ranked set samples that are required;}

VSP calculates the number of cycles, $r$, needed in the ranked set sampling design by using the values of $n_{0}, m$, and $R P$ as follows:

$$
r=\left(\frac{n_{o}}{m}\right) \times\left(\frac{1}{R P}\right)
$$

Where,

$r \quad$ is the number of cycles,

$n_{0} \quad$ is the number of samples required under simple random sampling,

$m \quad$ is the set size specified by the VSP user, 
$R P \quad$ is the relative precision.

5. Compute the total number of ranked set samples, $n$, that should be collected and measured to estimate the mean;

The number of field locations that are sampled and taken to the laboratory for measurement is calculated by VSP as

$n=r^{*} m$

where,

$n \quad$ is the number of samples that are measured,

$r \quad$ is the number of cycles,

$m \quad$ is the set size.

The values of these inputs that result in the calculated number of sampling locations are:

\begin{tabular}{|c|c|}
\hline Parameter & Value \\
\hline$m$ & 3 \\
\hline$s$ & 2 \\
\hline$d$ & 1 \\
\hline$\alpha$ & $5 \%$ \\
\hline$t_{1-\alpha / 2, \mathrm{df}}$ & $2.10982^{\mathrm{a}}$ \\
\hline$R P$ & $1.914^{\mathrm{b}}$ \\
\hline$r$ & 2 \\
\hline
\end{tabular}

${ }^{a}$ This value is automatically calculated by VSP based upon the user defined value of $\alpha$.

${ }^{b}$ This value is automatically calculated by VSP based upon the set size.

\section{Statistical Assumptions}

The assumptions used to determine the number of balanced RSS are:

1. The sample mean is normally distributed (used to compute $\mathrm{n}_{\mathrm{o}}$ ),

2. The variance estimate, $s^{2}$, is reasonable and representative of the population being sampled (used to compute $\mathrm{n}_{\mathrm{o}}$ ),

3. The data distribution is symmetric and approximately normally distributed (used to determine the $R P)$,

4. The estimate of the sample mean is reasonable and representative of the population being sampled, and,

5. The field locations that will be ranked are selected using simple random sampling.

The first three assumptions will be assessed in a post data collection analysis. The fourth assumption is valid because the estimate of the mean will be an unbiased estimate of the mean. 


\section{Sensitivity Analysis}

The sensitivity of the calculation of number of samples was explored by varying the standard deviation, confidence level $(1-\alpha)(\%)$, width of confidence interval and set size. The following table shows the results of this analysis.

\begin{tabular}{|c|c|c|c|c|c|c|c|}
\hline \multicolumn{8}{|c|}{ Number of Samples } \\
\hline \multirow{2}{*}{\multicolumn{2}{|c|}{$\begin{array}{c}\text { Confidence } \\
\text { Level/Interval }\end{array}$}} & \multicolumn{2}{|c|}{$\mathrm{m}=2$} & \multicolumn{2}{|c|}{$\mathrm{m}=3$} & \multicolumn{2}{|c|}{$\mathrm{m}=4$} \\
\hline & & $s=4$ & $\mathrm{~s}=2$ & $s=4$ & $\mathrm{~s}=2$ & $s=4$ & $\mathrm{~s}=2$ \\
\hline \multirow{3}{*}{$\mathrm{CL}=99$} & $\mathrm{~d}=0.5$ & 294 & 76 & 225 & 60 & 184 & 48 \\
\hline & $d=1$ & 76 & 22 & 60 & 18 & 48 & 16 \\
\hline & $\mathrm{d}=1.5$ & 36 & 12 & 27 & 9 & 24 & 8 \\
\hline \multirow{3}{*}{$\mathrm{CL}=97$} & $\mathrm{~d}=0.5$ & 208 & 54 & 162 & 42 & 132 & 36 \\
\hline & $d=1$ & 54 & 16 & 42 & 12 & 36 & 12 \\
\hline & $\mathrm{d}=1.5$ & 26 & 10 & 21 & 9 & 16 & 8 \\
\hline \multirow{3}{*}{$\mathrm{CL}=95$} & $\mathrm{~d}=0.5$ & 170 & 44 & 132 & 36 & 108 & 28 \\
\hline & $d=1$ & 44 & 14 & 36 & 12 & 28 & 8 \\
\hline & $\mathrm{d}=1.5$ & 22 & 8 & 18 & 6 & 16 & 8 \\
\hline \multirow{3}{*}{$\mathrm{CL}=93$} & $\mathrm{~d}=0.5$ & 146 & 38 & 114 & 30 & 92 & 24 \\
\hline & $d=1$ & 38 & 12 & 30 & 9 & 24 & 8 \\
\hline & $\mathrm{d}=1.5$ & 18 & 6 & 15 & 6 & 12 & 4 \\
\hline \multirow{3}{*}{$\mathrm{CL}=91$} & $\mathrm{~d}=0.5$ & 128 & 34 & 99 & 27 & 80 & 24 \\
\hline & $d=1$ & 34 & 10 & 27 & 9 & 24 & 8 \\
\hline & $\mathrm{d}=1.5$ & 16 & 6 & 15 & 6 & 12 & 4 \\
\hline
\end{tabular}

This report was automatically produced* by VSP software version 5.3 .

Software and documentation available at http://dqo.pnl.gov/vsp

Software copyright (c) 2009 Battelle Memorial Institute. All rights reserved.

* - The report contents may have been modified or reformatted by end-user of software. 